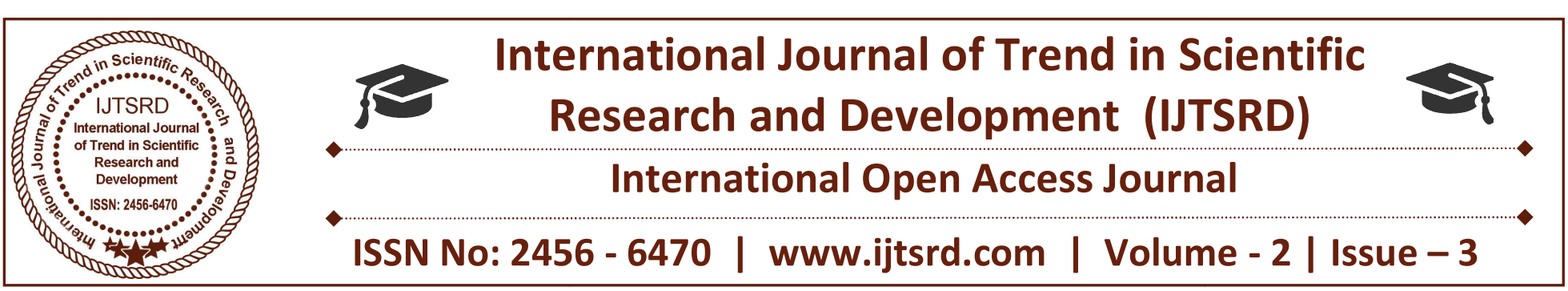

\title{
Structural Analysis and Design of Structural Elements of A Building
}

\author{
Potharaboyena Vinay \\ Assistant Professor, Vaagdevi College of \\ Engineering, Warangal, India
}

\author{
Kurimilla Srilaxmi \\ Assistant Professor, SR Engineering Colleges \\ Engineering College, Warangal, India
}

\section{INTRODUCTION}

\subsection{General}

Engineering is a professional art of applying science to the efficient conversion of natural resources for the benefit of man. Engineering therefore requires above all creative imagination to innovative useful application for natural phenomenon.

The design process of structural planning and design requires not only imagination and conceptual thinking but also sound knowledge of science of structural engineering besides the knowledge of practical aspects, such as recent design codes, bye laws, backed up by ample experience, intuition and judgment. The purpose of standards is to ensure and enhance the safety, keeping careful balance between economy and safety.

The process of design commences with planning of the structure, primarily to meet its functional requirements. Initially, the requirements proposed by the client are taken into consideration. They may be vague, ambiguous or even unacceptable from engineering point of view because he is not aware of the various implications involved in the process of planning and design, and about the limitations and intricacies of structural science.

It is emphasized that any structure to be constructed must satisfy the need efficiently for which it is intended and shall be durable for its desired life span.

Thus, the design of any structure is categorized into the following two main types

1) Functional design

2) Structural design.

\section{Functional design}

The structure to be constructed should be primarily serve the basic purpose for which it is to be used and must have a pleasing look.

The building should provide happy environment inside as well as outside. Therefore, the functional planning of a building must take into account the proper arrangements of rooms / halls to satisfy the need of the client, good ventilation, lighting, acoustics, unobstructed view in the case of community halls, cinema halls, etc.. sufficient head room, proper water supply and drainage arrangements, planting of trees etc. bearing all these aspects in mind the architect/engineer has to decide whether it should be a load bearing structure or R.C.C framed structure or a steel structure etc..

\section{Structural design}

Structural design is an art and science of understanding the behavior of structural members subjected to loads and designing them with economy and elegance to give a safe, serviceable and durable structure.

\subsection{Study objectives}

1. To make a study about the analysis and design of building.

2. To make a study about the guidelines for the design of principle elements of a R.C building frame according to IS code.

3. To analyze manually the problem frame, using Substitute Frame method under vertical loading conditions. 
4. To make a study about the methods of structural analysis.

5. To get familiar with the structural software(AutoCAD)

\subsection{Report organization}

In this project report, each chapter deals with different aspects of the project as shown below

CHAPTER 1 Gives brief introduction of the project. CHAPTER 2 Gives information about the literature used.

CHAPTER 3 Structural analysis and reinforcement details are discussed in this chapter.

CHAPTER 4 Analysis and Design of building is discussed.

CHAPTER 5 Results/ drawings of reinforcement details are discussed in this chapter

CHAPTER 6 Conclusions drawn from the project work are discussed in this chapter.

\section{CHAPTER-2}

\section{REVIEW OF LITERATURE}

Hardy Cross has investigated on moment distribution method over continuous frames based on the pipe flow network revolutionized from MUNICIPAL WATER SUPPLY DESIGN. This method was first published in November 1936 by its name sake by Hardy on a structural analysis method for statically indeterminate beams and frames. It only accounts for flexural effects and ignores axial and shear effects. In 1930 Hardy published a paper called "ANALYSIS OF CONTINUOUS FRAMES BY DISTRIBUTION OF END MOMENTS." Which lead to MOMENT DISTRIBUTION METHOD.

Hardy cross method is application of continuity of flow and continuity of potential in which flow is equal in all directions. He accomplished the task by distributing unbalanced moments known as CROSS METHOD.

Galileo Galilei (1564-1642) has worked on theory of structures. In his book entitled Two New Science which was published in 1638, Galileo analyzed the failure of some simple structures, including cantilever beams. Although Galileo's predictions on strengths of beams were only approximate, his work laid the foundation for future developments in the theory of structures and ushered in a new era of structural engineering, in which the analytical principles of mechanics and strength of materials would have a major influence on the design of structures. Following Galileo's pioneering work, the knowledge of structural mechanics advanced at a rapid pace in the second half of the seventeenth century and into the eighteenth century.

Leonhard Euler (1707-1783) has investigated on the theory of buckling of columns. He was the first person to realize that the failure of slender columns takes place because of buckling. He formulated his famous equation in 1744 for predicting the buckling load of columns which are not stressed above the proportional limits and proposed that buckling involves parameters such as shaft section\& elastic properties, coupling strength \& stiffness, soil strength\& stiffness and the eccentricity of applied load. He solved the question of critical compression load with $\mathbf{P}_{\mathbf{c r}}=\frac{\boldsymbol{\pi}^{2} \mathbf{E I}}{\left(\mathbf{k L}_{\mathbf{u}}\right)^{2}}$ and proved buckling of columns refers to allowable compression load for a given unsupported length. He gave his famous analysis of the buckling of initially straight beams subjected to compressive strength; such beams are called as columns.

Heinrich Manderla has worked on slope deflection method in case of beams with unyielding supports. He found that unknown slopes and deflections at nodes are related to applied loading on structures. Earlier, slope deflection method can be used to analyze statically determinate beams and frames. In this method he assumed that deformations in a structure are due to bending only which means deformations due to axial loads is neglected. Slope deflection method is developed by Manderla and O.H.O Mohr for computing secondary stresses in trusses. Today used slope deflection method was presented by G.A.Maney in 1915 for analyzing rigid jointed structures. The fundamental slope deflection equations expresses the moment at the end of member as the superposition of the end moments caused due to external loads on the members.

Professor Gasper Kani has investigated on substitute frames for the analysis of indeterminent structures in 1947.this method offered an iterative scheme for applying slope deflection method. This method is applicable for: (1) beams with no translation of joints, (2) rotation factor of multi-storied frames, (3) analyzing of frames with no translation of joints etc. This method is an indirect extension of slope deflection method and is efficient due to simplicity of moment distribution. In Kani's method all the 
components are carried out in a single line diagram of the structure. His method is convenient for multistoried building frames in vertical and lateral loading conditions as it is self correcting.

Claude-Louis Navier has worked out on the elastic behavior of structures in mathematical form in 1821 making it available to the field of construction with sufficient accuracy in 1826 as elastic formed as a basic until World War II when bombs damaged buildings was unpredictable. Navier is considered as a founder of modern structure analysis. He published elastic theory of beams in 1826 along with three methods for analyzing forces in trusses.

Daniel Bernoulli has investigated on the structural technology such as beams and columns. In 1705, he proposed a paper that the curvature of beams is directly proportional to its bending moment and used this theory to address the transverse vibrations of beams. Euler following Bernoulli introduced the concept of strain energy per unit length of beam is directly proportional to the beam curvature.

\section{CHAPTER-3}

\section{STRUCTURAL ANALYSIS AND GUIDELINES FOR REINFORCEMENT}

\subsection{Structural analysis}

A structure refers to a system of two or more connected parts use to support a load. It is an assemblage of two or more basic components connected to each other so that they serve the user and carry the loads developing due to the self and superimposed loads safely without causing any serviceability failure. Once a preliminary design of a structure is fixed, the structure then must be analyzed to make sure that it has its required strength and rigidity. To analyze a structure a structure correctly, certain idealizations are to be made as to how the members are supported and connected together. The loadings are supposed to be taken from respective design codes and local specifications, if any. The forces in the members and the displacements of the joints are found using the theory of structural analysis. The whole structural system and its loading conditions might be of complex nature so to make the analysis simpler, we use certain simplifying assumptions related to the quality of material, member geometry, nature of applied loads, their distribution, the type of connections at the joints and the support conditions. This shall help making the process of structural analysis simpler to quite an extent.

\section{Methods of structural analysis}

When the number of unknown reactions or the number of internal forces exceeds the number of equilibrium equations available for the purpose of analysis, the structure is called as a statically indeterminate structure. Most of the structures designed today are statically indeterminate.

While analyzing any indeterminate structure, it is essential to satisfy equilibrium, compatibility, and force-displacement requisites for the structure. When the reactive forces hold the structure at rest, equilibrium is satisfied and compatibility is said to be satisfied when various segments of a structure fit together without intentional breaks or overlaps.

Two fundamental methods to analyze the statically indeterminate structures are discussed below.

\section{Force methods}

Originally developed by James Clerk Maxwell in 1864, later developed by Otto Mohr and Heinrich Muller-Breslau. As compatibility is the basis for this method, it is sometimes also called as compatibility method or the method of consistent displacements. In this method, equations are formed that satisfy the compatibility and force-displacement requirements for the given structure in order to determine the redundant forces. Once these forces are determined, the remaining reactive forces on the given structure are found out by satisfying the equilibrium requirements.

\section{Displacement methods}

In these methods, we first write load-displacement relations for the members of the structure and then satisfy the equilibrium requirements for the same. In here, the unknowns in the equations are displacements. Unknown displacements are written in terms of the loads (i.e. forces) by using the loaddisplacement relations and then these equations are solved to determine the displacements. As the displacements are determined, the loads are found out from the compatibility and load- displacement equations. Some classical techniques used to apply the displacement method are discussed.

\section{Slope deflection method}

This method was devised by Heinrich Manderla and Otto Mohr to study the secondary stresses in trusses. The basic assumption of this method is to consider the deformations caused only by bending moments. It's assumed that the effects of shear force or axial force 
deformations are negligible in indeterminate beams or frames.

The fundamental slope-deflection equation expresses the moment at the end of a member as the superposition of the end moments caused due to the external loads on the member, while the ends being assumed as restrained, and the end moments caused by the displacements and actual end rotations. A structure comprises of several members, slopedeflection equations are applied to each of the member. Using appropriate equations of equilibrium for the joints along with the slope-deflection equations of each member we can obtain a set of simultaneous equations with unknowns as the displacements. Once we get the values of these unknowns i.e. the displacements we can easily determine the end moments using the slope-deflection equations.

\section{Moment distribution method}

This method of analyzing beams and multi-storey frames using moment distribution was introduced by Prof. Hardy Cross in 1930, and is also sometimes referred to as Hardy Cross method. It is an iterative method in which one goes on carrying on the cycle to reach to a desired degree of accuracy. To start off with this method, initially all the joints are temporarily restrained against rotation and fixed end moments for all the members are written down. Each joint is then released one by one in succession and the unbalanced moment is distributed to the ends of the members, meeting at the same joint, in the ratio of their distribution factors. These distributed moments are then carried over to the far ends of the joints. Again the joint is temporarily restrained before moving on to the next joint. Same set of operations are performed at each joints till all the joints are completed and the results obtained are up to desired accuracy. The method does not involve solving a number of simultaneous equations, which may get quite complicated while applying large structures, and is therefore preferred over the slope-deflection method.

\section{Kani's method}

This method was first developed by Prof. Gasper Kani of Germany in the year 1947. The method is named after him. This is an indirect extension of slope deflection method. This is an efficient method due to simplicity of moment distribution. The method offers an iterative scheme for applying slope deflection method of structural analysis. Whereas the moment distribution method reduces the number of linear simultaneous equations and such equations needed are equal to the number of translator displacements, the number of equations needed is zero in case of the Kani's method.

This method may be considered as a further simplification of moment distribution method wherein the problems involving sway were attempted in a tabular form thrice (for double story frames) and two shear coefficients had to be determined which when inserted in end moments gave us the final end moments. All this effort can be cut short very considerably by using this method.

Frame analysis is carried out by solving the slope-deflection equations by successive approximations. Useful in case of side sway as well.

Operation is simple, as it is carried out in a specific direction. If some error is committed, it will be eliminated in subsequent cycles if the restraining moments and distribution factors have been determined correctly.

\subsection{Method of substitute frames}

A substitute frame consists of a small portion of the multistory, multi-bay frame generally comprising of the floor beams, with the columns above and below the floor assumed to be fixed at the far ends as shown in figure 1 .

It is sufficient to consider the loads on the two nearest spans on each side of the joint under consideration. The continuous beam is analyzed for vertical loads by moment distribution to compute the maximum span and support moments using the following criterion:

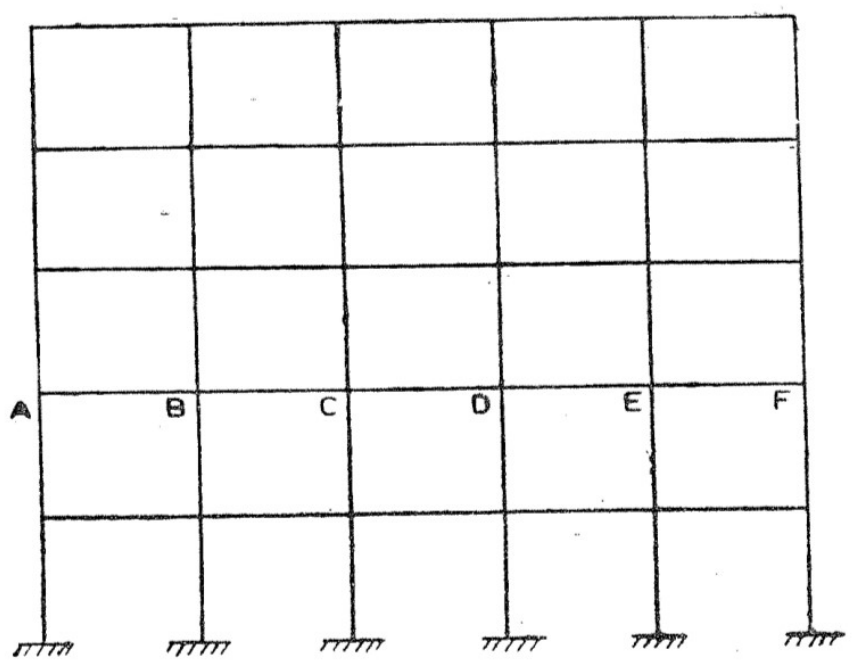




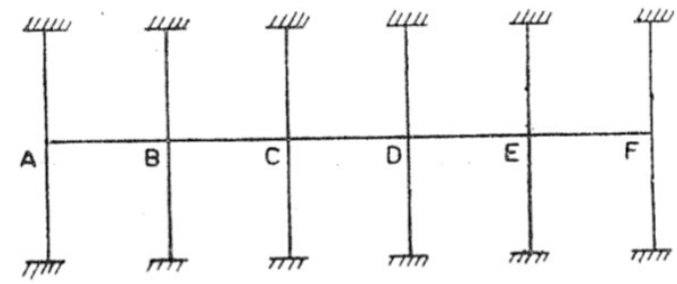

Figure-1: Multi storey - multi bay building frame

(a) The maximum positive bending moment at midpoint of any particular span develops when the load is placed on the span under consideration and on the alternate span as shown in figure 2.

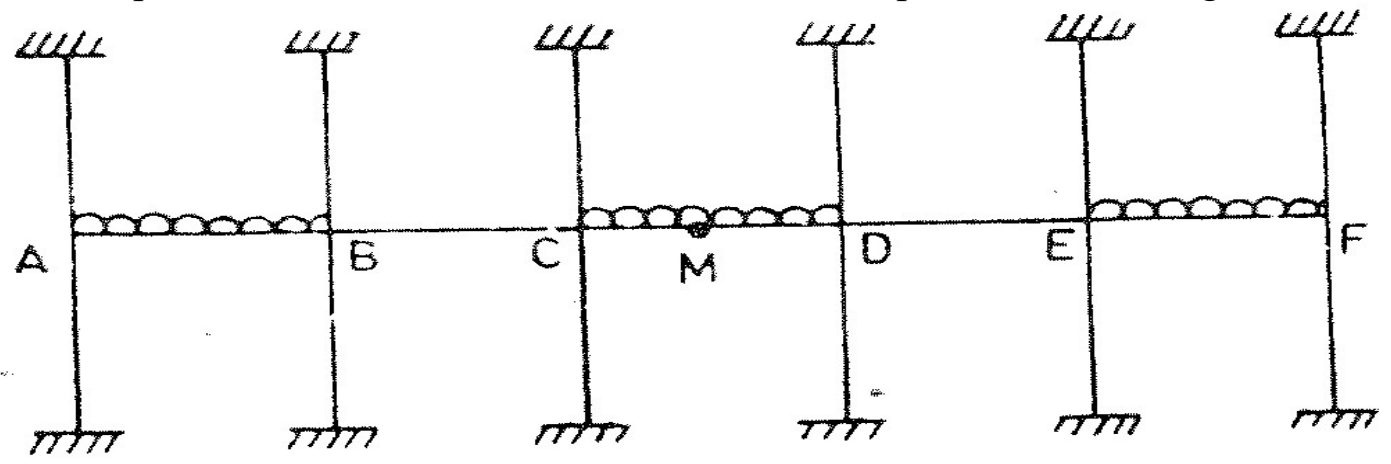

Figure-2: Loading for maximum positive B.M at M

(b) The maximum negative bending moment at any particular support develops when the loads are placed on two spans adjacent to the support under consideration as shown in figure 3.

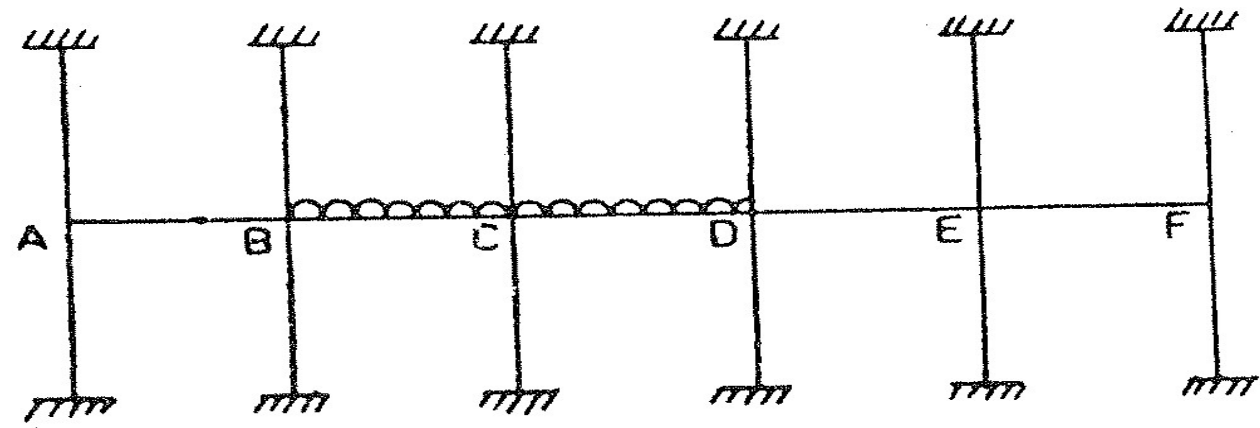

Figure-3: Loading for maximum negative B.M at C

(c) The maximum negative bending moment at midpoint of any particular span develops when the loads are placed on the spans adjacent to the span under consideration as shown in figure 4.

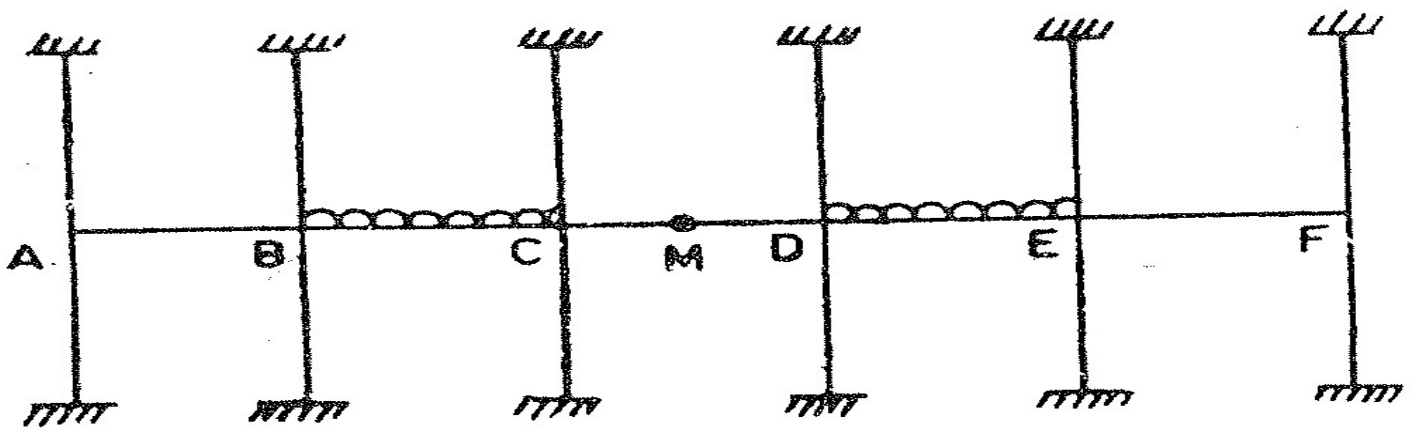

Figure-4: Loading for maximum negative B.M at M 


\subsection{Reinforcement Details}

\subsubsection{Beams}

1. Minimum tension reinforcement: The minimum area of tension reinforcement should not be less than $\frac{A_{o}}{b d}=\frac{0.85}{\sigma_{y}}$

2. Maximum reinforcement: The maximum reinforcement in tension or compression should not exceed $0.04 \mathrm{bD}$, (where $\mathrm{D}=$ over all depth of section)

3. Side face reinforcement: If depth of web in beam exceeds $750 \mathrm{~mm}$, side face reinforcement should be provided along the two faces. The total area of such reinforcement should not be less than $0.1 \%$ of web area. It should be equally distributed on two faces. The spacing of such reinforcement should not exceed $300 \mathrm{~mm}$ or web thickness whichever is less.

4. Spacing of shear reinforcement: For vertical shear stirrups, maximum spacing along the axis of the member is restricted to $0.75 \mathrm{~d}$. For inclined shear bars, maximum spacing measured along the axis of the member should not exceed the effective depth $\mathrm{d}$. In any case the maximum of shear stirrups is limited to $300 \mathrm{~mm}$. The minimum spacing of shear stirrups should be limited to $75 \mathrm{~mm}$ to $100 \mathrm{~mm}$ in order to ensure proper compaction to concrete.

5. Minimum shear reinforcement: Even if calculations show that a beam has sufficient shear strength and shear stirrups are not required, a small quantity of shear stirrups is still provided. The reason is that tensile forces may be induced into a beam through shrinkage or some restraint which will reduce the shear strength of concrete in the compression zone. Minimum shear reinforcement is to be provided if nominal shear stress $\tau_{\mathrm{v}}$ is less than or equal to shear strength of concrete. The spacing $\mathrm{x}$ of shear stirrups is given by: $x=\frac{0.87 \sigma_{y} A_{o}}{0.4 b}$

\subsubsection{Slabs}

Minimum reinforcement: The minimum reinforcement in either direction in slabs should not be less than $0.15 \%$ of total cross-sectional area using mild steel reinforcement \& $0.12 \%$ of total crosssectional area using high strength deformed reinforcement or welded wire fabric. The maximum diameter of reinforcing bars should not exceed $1 / 8^{\text {th }}$ of total thickness of slab.

\subsubsection{Columns}

There are two types of reinforcements in columns: longitudinal reinforcement and transverse reinforcement. The purpose of transverse reinforcement is to hold vertical bars in position providing lateral supports so that individual bars cannot buckle outwards and split the concrete. Transverse reinforcement doesn't contribute to strength of a column directly.

\section{Longitudinal reinforcement}

1. The minimum area of cross-section of longitudinal bars must be less atleast $0.8 \%$ nor more than $6 \%$ of the gross-sectional area of the column.

2. In any column that has a larger cross-sectional area more than the required to support the load, the minimum steel $\%$ is based on the area of concrete required to resist the direct stress and not upon the actual area.

3. The minimum number of longitudinal bars provided a column shall be 4 in rectangular columns \& 6 in circular columns.

4. The bars shall not be less than $12 \mathrm{~mm}$ in diameter.

5. A reinforced concrete column having helical reinforcement shall have atleast 6 bars of longitudinal reinforcement.

6. In a helically reinforced column, the longitudinal bars shall be in contact with the helical reinforcement and equidistant around its inner circumference.

7. Spacing of longitudinal bars measured along the periphery of the column shall not exceed $300 \mathrm{~mm}$.

8. In case of pedestals in which longitudinal reinforcement isn't taken into account in strength calculations, nominal longitudinal reinforcement not less than $0.15 \%$ of the cross sectional area shall be provided.

\section{transverse reinforcement}

Transverse reinforcement may be in the form of lateral ties or spirals. The lateral ties may be in the form of polygonal links with internal angles not exceeding $135^{\circ}$. The ends of transverse reinforcement should be properly anchored. It should satisfy the following:

1. If the longitudinal bars are not spaced more than $75 \mathrm{~mm}$ on either side, transverse reinforcement need only to go round corner and alternate bars for the purpose of providing effective lateral supports.

2. If the longitudinal bars spaced at a distance not exceeding 48 times the diameter of the tie are effectively tied in both the directions, additional 
longitudinal bars in between these bars are to be tied in one direction by open ties.

3. Where the longitudinal reinforcing bars in a compression members are placed in more than one row, effective lateral supports to the longitudinal bars in the inner rows may be assumed to have been provided if:

i. Transverse reinforcement is provided for the outer-most row.

ii. No bar of the inner row is closer to the nearest compression face than 3times the diameter of the largest bar in the inner row.

4. Where the longitudinal bars in a compression member are grouped such that they are not in contact and each group is adequately tied with transverse reinforcement.

\section{CHAPTER-4}

\section{ANALYSIS AND DESIGN}

\subsection{Approximate analysis for vertical loads / Substitute frame method:}

Consider a building frame as shown in figure 5. Any typical beam in this building frame is subjected to axial force, bending moment and shear force.

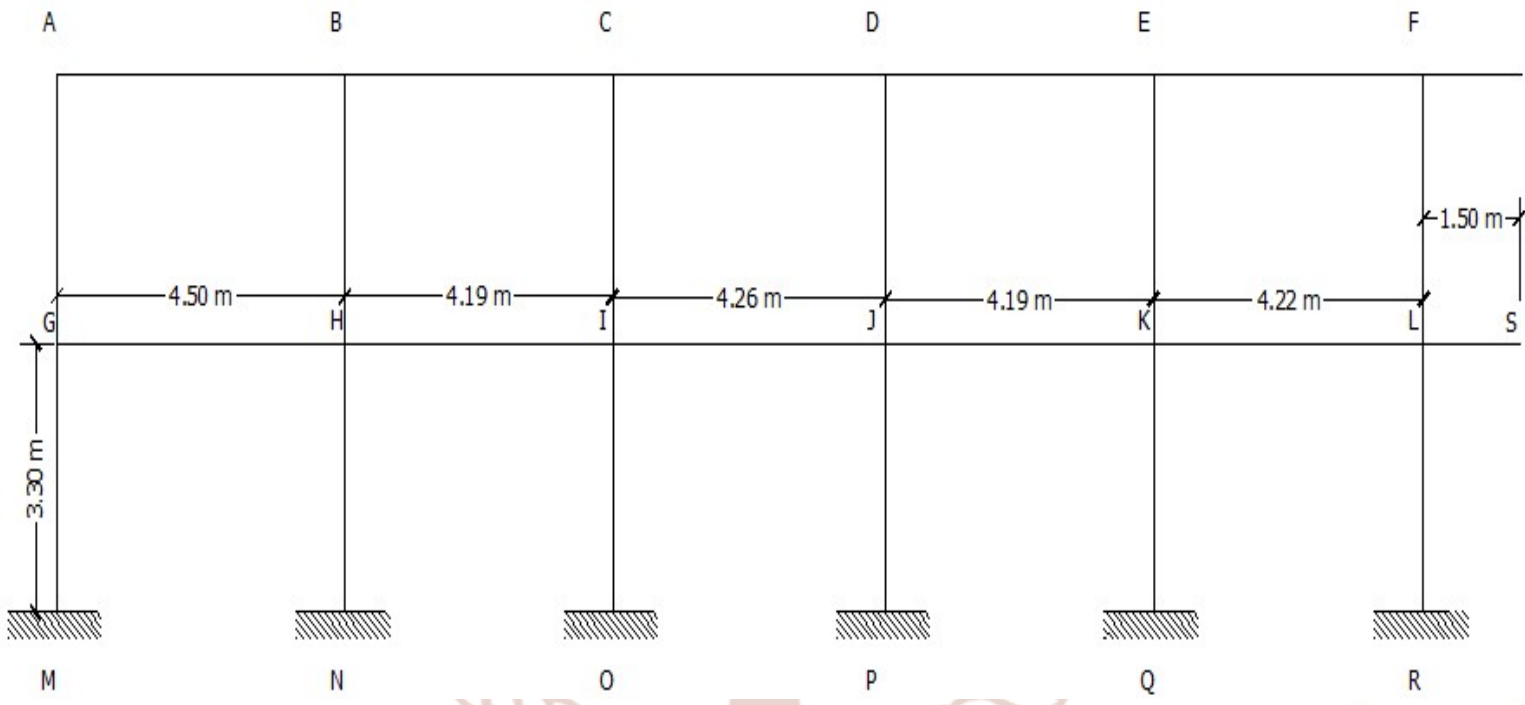

Figure 5: Building frame

\section{lateral ties}

1. The diameter of the polygonal links or lateral ties should not be less than $1 / 4^{\text {th }}$ of the diameter of the largest longitudinal bar, and in no case less than $6 \mathrm{~mm}$.

2. The pitch of the lateral ties should not exceed the following distances:

i. The least lateral dimension of the compression member.

ii. 16 times the smallest diameter of the longitudinal reinforcement bar to be tied, and

iii. $300 \mathrm{~mm}$.

\section{Assumptions:}

Slab thickness $=0.15 \mathrm{~m}$

Beam section $=0.23 \times 0.46 \mathrm{~m}$

Density of concrete used $=25 \mathrm{KN} / \mathrm{m}^{3}$

Live load for office building $=3 \mathrm{KN} / \mathrm{m}^{2}$

Column sections
$\mathrm{GA}, \mathrm{GM}=0.23 \times 0.46 \mathrm{~m}$
$\mathrm{HB}, \mathrm{HN}=0.30 \times 0.60 \mathrm{~m}$
$\mathrm{IC}, \mathrm{IO}=0.30 \times 0.60 \mathrm{~m}$
$\mathrm{JD}, \mathrm{JP}=0.30 \times 0.60 \mathrm{~m}$
$\mathrm{KE}, \mathrm{KQ}=0.30 \times 0.60 \mathrm{~m}$
$\mathrm{LF}, \mathrm{LR}=0.23 \times 0.46 \mathrm{~m}$ 
International Journal of Trend in Scientific Research and Development (IJTSRD) ISSN: 2456-6470

\section{Substitute Frame Method:}

1. 1st floor of the frame was considered.

2. Column ends of the floor on both sides were assumed to be fixed.

3. Distribution factors depending upon the member stiffness were calculated for each member.

Relative stiffness $=\frac{\mathrm{I}}{\mathrm{L}}=\frac{\mathrm{bd}^{3}}{12} \frac{1}{\mathrm{~L}}$

Distribution factor $=\frac{\text { Relative stiffness }}{\text { Total stiffness }}$

4. Total FEM $M_{S}$ and dead load FEM $M_{s}$ were calculated with all spans loaded.

Dead load FEM $=\frac{\mathrm{W}_{\mathrm{dl}} \mathrm{L}^{2}}{12}$

Total load FEM $=\frac{\mathrm{w}_{\mathrm{tl}} \mathrm{L}^{2}}{12}$

5. Distribution of moments was performed to get the final end moments.

\begin{tabular}{|c|c|c|c|c|}
\hline Joint & Member & $\begin{array}{l}\text { Relative } \\
\text { stiffoness }\end{array}$ & Total stiffiness & $\begin{array}{l}\text { Distribution } \\
\text { factor }\end{array}$ \\
\hline $\mathrm{G}$ & $\begin{array}{l}\text { GA } \\
\text { GH } \\
\text { GM }\end{array}$ & $\begin{array}{l}5.65 \times 10^{-4} \\
4.14 \times 10^{-4} \\
5.65 \times 10^{-4}\end{array}$ & $1.54 \times 10^{-}$ & $\begin{array}{l}0.36 \\
0.27 \\
0.37\end{array}$ \\
\hline $\mathrm{H}$ & $\begin{array}{l}\mathrm{HG} \\
\mathrm{HI} \\
\mathrm{HN} \\
\mathrm{HB} \\
\end{array}$ & $\begin{array}{l}4.14 \times 10^{-4} \\
4.45 \times 10^{-4} \\
1.63 \times 10^{-3} \\
1.63 \times 10^{-3}\end{array}$ & $4.11 \times 10^{-}$ & $\begin{array}{l}0.10 \\
0.10 \\
0.40 \\
0.40\end{array}$ \\
\hline I & $\begin{array}{l}\text { IH } \\
\text { IJ } \\
\text { IO } \\
\text { IC }\end{array}$ & $\begin{array}{l}4.45 \times 10^{-4} \\
4.37 \times 10^{-4} \\
1.63 \times 10^{-3} \\
1.63 \times 10^{-3}\end{array}$ & $4.14 \times 10^{-3}$ & $\begin{array}{l}0.11 \\
0.11 \\
0.39 \\
0.39\end{array}$ \\
\hline $\mathrm{J}$ & $\begin{array}{l}\mathrm{JI} \\
\mathrm{JK} \\
\mathrm{JP} \\
\mathrm{JO}\end{array}$ & $\begin{array}{l}4.37 \times 10^{-4} \\
4.45 \times 10^{-4} \mathrm{Ch} \\
1.63 \times 10^{-3} \\
1.63 \times 10^{-3}\end{array}$ & $4.14 \times 10^{-3}$ & $\begin{array}{l}0.11 \\
0.11 \\
0.39 \\
0.39 \\
\end{array}$ \\
\hline $\mathrm{K}$ & $\begin{array}{l}\mathrm{KJ} \\
\mathrm{KL} \\
\mathrm{KQ} \\
\mathrm{KE} \\
\end{array}$ & $\begin{array}{l}4.45 \times 10^{-4} \\
4.42 \times 10^{-4} 6=6 \\
1.63 \times 10^{-3} \\
1.63 \times 10^{-3}\end{array}$ & $4.14 \times 10^{-3}$ & $\begin{array}{l}0.11 \\
0.11 \\
0.39 \\
0.39 \\
\end{array}$ \\
\hline $\mathrm{L}$ & $\begin{array}{l}\text { LK } \\
\text { LR } \\
\text { LF } \\
\text { LS } \\
\end{array}$ & $\begin{array}{l}4.42 \times 10^{-4} \\
5.65 \times 10^{-4} \\
5.65 \times 10^{-4} \\
0\end{array}$ & $1.57 \times 1 C$ & $\begin{array}{l}0.28 \\
0.36 \\
0.36 \\
0 \\
\end{array}$ \\
\hline
\end{tabular}

Table 1: Distribution factors

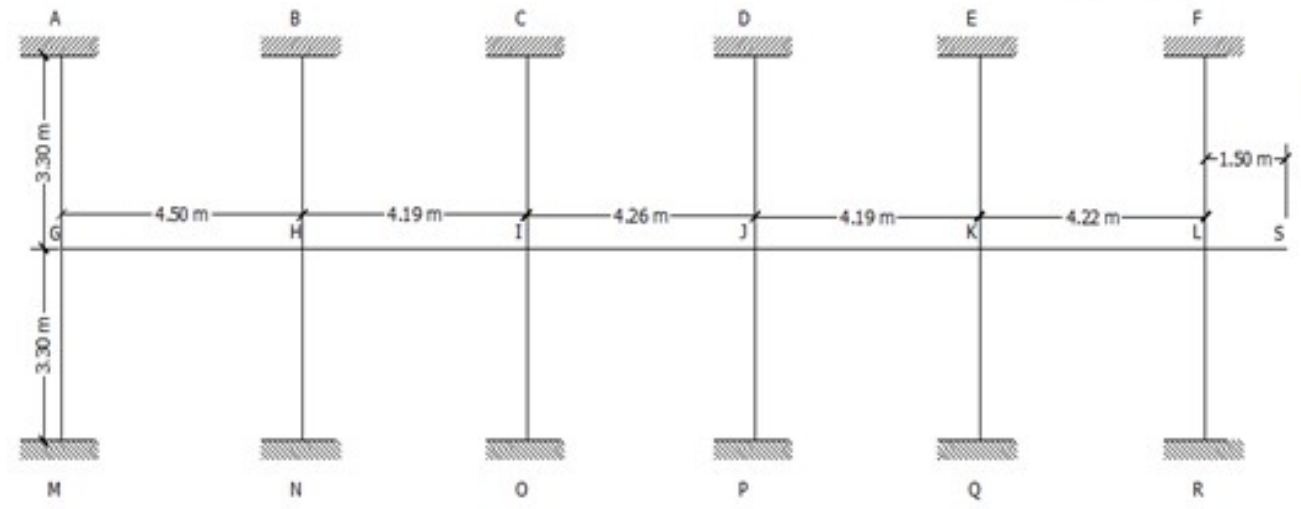

Figure 6: First floor analysis of building frame 
International Journal of Trend in Scientific Research and Development (IJTSRD) ISSN: 2456-6470

Self weight of beam $=0.23 \times 0.46 \times 25$

$$
=2.645 \mathrm{KN} / \mathrm{m}
$$

Dead load from slab per meter run of girder $=3.75 \times\left(\frac{2.65+5.41}{2}\right)$

$$
\begin{aligned}
& =3.75 \times 4.03 \\
& =15.11 \mathrm{KN} / \mathrm{m}
\end{aligned}
$$

Live load per meter run of girder $=3 \times 4.03$

$$
=12.09 \mathrm{KN} / \mathrm{m}
$$

Fixed end moments for dead load and total load for girders are shown in table 4.2

\begin{tabular}{|l|l|l|}
\hline Span & Dead load FEM (KN) & Total load FEM (KN) \\
\hline GH & 29.95 & 50.36 \\
\hline HI & 25.97 & 43.66 \\
\hline IJ & 26.85 & 45.13 \\
\hline JK & 25.97 & 43.66 \\
\hline KL & 26.35 & 44.29 \\
\hline LS & 3.32 & 5.59 \\
\hline
\end{tabular}

Table 2: Fixed end moments

\section{Moment Distribution of maximum negative B.M at Joints}

\section{Joint G}

\begin{tabular}{|l|l|l}
\hline Joint & G & H \\
\hline
\end{tabular}

Member

Distribution factor

1.D.L.F.E.M

2.T.L.F.E.M

GH of Irend II $\mathrm{HG}$

3.Distribute and carry -1.21

over

4.Add(2) and (3)

5.Distribute

0.27

0.10

HI

6.Total(sum of 4 and 5) $\quad-37.65$

Table 3: Maximum negative B.M at Joint G

\section{Joint H}

\begin{tabular}{|l|l|l|l|l|l|}
\hline Joint & G & H & I \\
\hline Member & GH & HG & HI & IH & IJ \\
\hline Distribution factor & 0.27 & 0.10 & 0.10 & 0.11 & 0.11 \\
\hline 1.D.L.F.E.M & & & & & -26.84 \\
2.T.L.F.E.M & -50.36 & +50.36 & -43.66 & +43.66 & \\
3.Distibute and carry over & +13.59 & +6.79 & -0.92 & -1.85 & \\
\hline 4.Add (2) and (3) & & +57.15 & -44.58 & & \\
5.Distribute & & -1.25 & -1.25 & & \\
\hline 6.Total(sum of 4 and 5) & & +55.9 & -45.83 & & \\
\hline
\end{tabular}

Table 4: Maximum negative B.M at Joint H

\section{Joint I}

\begin{tabular}{|l|l|l|l|l|l|l|}
\hline Joint & H & I & J \\
\hline Member & HG & HI & IH & IJ & JI & JK \\
\hline Distribution factor & 0.27 & 0.10 & 0.11 & 0.11 & 0.11 & 0.11 \\
\hline $\begin{array}{l}\text { 1.D.L.F.E.M } \\
\text { 2.T.L.F.E.M }\end{array}$ & +29.95 & & & & & -25.97 \\
\hline
\end{tabular}


International Journal of Trend in Scientific Research and Development (IJTSRD) ISSN: 2456-6470

\begin{tabular}{|l|l|l|l|l|l|l|}
\hline 3.Distribute and carry over & & +1.37 & +0.68 & -1.05 & -2.10 & \\
\hline 4.Add (2) and (3) & & & +44.34 & -46.18 & & \\
5.Distribute & & & +0.20 & +0.20 & & \\
\hline 6. Total(sum of 4 and 5) & & & +44.54 & -45.98 & & \\
\hline
\end{tabular}

Table 5: Maximum negative B.M at Joint I

\section{Joint J}

\begin{tabular}{|l|l|l|l|l|l|l|}
\hline Joint & I & J & K \\
\hline Member & IH & IJ & JI & JK & KJ & KL \\
\hline Distribution factor & 0.11 & 0.11 & 0.11 & 0.11 & 0.11 & 0.11 \\
\hline 1.D.L.F.E.M & +25.97 & & & & & -26.35 \\
2.T.L.F.E.M & & -45.13 & +45.13 & -43.66 & +43.66 & \\
3.Distribute and carry over & & +2.10 & +1.05 & -0.95 & -1.90 & \\
\hline 4.Add (2) and (3) & & & +46.18 & -44.61 & & \\
5.Distribute & & -0.17 & -0.17 & & \\
\hline 6.Total(sum of 4 and 5) & & & +46.01 & -44.78 & & \\
\hline
\end{tabular}

\section{Joint K}

Table 6: Maximum negative B.M at Joint J

\begin{tabular}{|l|l|l|l|l|l|l|}
\hline Joint & J & K & L \\
\hline Member & JI & JK & KJ & KL & LK & LS \\
\hline Distribution factor & 0.11 & 0.11 & 0.11 & 0.11 & 0.28 & 0 \\
\hline 1.D.L.F.E.M & +26.85 & & & & & -3.32 \\
2.T.L.F.E.M & & -43.66 & +43.66 & -44.29 & +44.29 & \\
3.Distribute and carry over & & +1.84 & +0.92 & -5.73 & -11.47 & \\
\hline 4.Add (2) and (3) & & & +44.58 & -50.02 & & \\
5.Distribute & & & +0.59 & +0.59 & & \\
\hline 6.Total(sum of 4 and 5) & & & +45.17 & -49.43 & & \\
\hline
\end{tabular}

Table 7: Maximum negative B.M at Joint K

\section{Joint L}

\begin{tabular}{|l|l|l|l|l|}
\hline Joint & K & L \\
\hline Member & KJ & KL & LK & LS \\
\hline Distribution factor & $0.11 / 24$ & 0.11 & 0.28 & 0 \\
\hline 1.D.L.F.E.M & +25.97 & & & \\
2.T.L.F.E.M & & -44.29 & +44.29 & -5.59 \\
3.Distibute and carry over & & +2.01 & +1.00 & 0 \\
\hline 4.Add (2) and (3) & & & +45.29 & -5.59 \\
5.Distribute & & & -11.11 & \\
\hline 6.Total(sum of 4 and 5) & & & +34.18 & -5.59 \\
\hline
\end{tabular}

Table 8: Maximum negative B.M at Joint L

Moment Distribution for maximum positive B.M at Mid Spans

Mid Span of GH

\begin{tabular}{|c|c|c|c|c|c|}
\hline Joint & G & \multicolumn{2}{|l|}{$\mathrm{H}$} & \multicolumn{2}{|l|}{ I } \\
\hline Member & $\mathrm{GH}$ & $\mathrm{HG}$ & $\mathrm{HI}$ & $\mathrm{IH}$ & $\mathrm{IJ}$ \\
\hline Distribution factor & 0.27 & 0.10 & 0.10 & 0.11 & 0.11 \\
\hline $\begin{array}{l}\text { 1.D.L.F.E.M } \\
\text { 2.T.L.F.E.M }\end{array}$ & -50.36 & +50.36 & -25.97 & +25.97 & -45.13 \\
\hline $\begin{array}{l}\text { 3.Distribute } \\
\text { 4.carry over } \\
\text { 5.Distribute }\end{array}$ & $\begin{array}{l}+13.59 \\
-1.21 \\
+0.32\end{array}$ & $\begin{array}{l}-2.43 \\
+6.79 \\
-0.78 \\
\end{array}$ & +1.05 & +2.10 & \\
\hline Total & -37.66 & +53.94 & & & \\
\hline
\end{tabular}

Table 9: Maximum positive B.M at Mid Span of GH 
International Journal of Trend in Scientific Research and Development (IJTSRD) ISSN: 2456-6470

Positive B.M at Mid Span $=\frac{w l^{2}}{8}-\left(\frac{37.66+53.94}{2}\right)$

\section{Mid Span of HI}

$$
=\frac{3}{2} \times 50.36-45.8=29.74 \mathrm{KN}-\mathrm{m}
$$

\begin{tabular}{|l|l|l|l|l|l|l|l|l|}
\hline & G & \multicolumn{2}{l|}{ H } & \multicolumn{2}{l|}{ I } & J & K \\
\hline Member & GH & HG & HI & IH & IJ & JI & JK & KJ \\
\hline $\begin{array}{l}\text { Distribution } \\
\text { factor }\end{array}$ & 0.27 & 0.10 & 0.10 & 0.11 & 0.11 & 0.11 & 0.11 & 0.11 \\
\hline $\begin{array}{l}\text { 1.D.L.F.E.M } \\
\text { 2.T.L.F.E.M }\end{array}$ & -29.95 & +29.95 & -43.66 & +43.66 & -26.85 & +26.85 & & \\
\hline $\begin{array}{l}\text { 3.Distribute } \\
\text { 4.carry over } \\
\text { 5.Distribute }\end{array}$ & +8.08 & +4.04 & $\begin{array}{l}+1.37 \\
-0.92 \\
-0.31\end{array}$ & $\begin{array}{l}-1.84 \\
+0.68 \\
-0.17\end{array}$ & +0.92 & +1.84 & & \\
\hline Total & & & -43.52 & +42.33 & & & & \\
\hline
\end{tabular}

Table 10: Maximum positive B.M at Mid Span of HI

Positive B.M at Mid Span $=\frac{w l^{2}}{8}-\left(\frac{43.52+42.33}{2}\right)$

$$
=\frac{3}{2} \times 43.66-42.92
$$

$=22.57 \mathrm{KN}-\mathrm{m}$

\begin{tabular}{|c|c|c|c|c|c|c|c|c|}
\hline Joint & $\mathrm{HI}$ & & I & & J & & $\mathbf{K}$ & \\
\hline Member & $\mathrm{HG}$ & $\mathrm{HI}$ & $\mathrm{IH}$ & IJ & JI & JK & $\mathrm{KJ}$ & KL \\
\hline $\begin{array}{l}\text { Distribution } \\
\text { factor }\end{array}$ & 0.10 & 0.10 & 0.11 or & 0.11 & $0.11 \mathrm{IC}$ & 0.115 & 0.11 & 0.11 \\
\hline $\begin{array}{l}\text { 1.D.L.F.E.M } \\
\text { 2.T.L.F.E.M }\end{array}$ & +50.36 & -25.97 & $\begin{array}{l}+25.97 \\
\text { Deve }\end{array}$ & -45.13 & +45.13 & -25.97 & +25.97 & -44.29 \\
\hline $\begin{array}{l}\text { 3.Distribute } \\
\text { 4.carry over } \\
\text { 5.Distribute }\end{array}$ & & -2.43 & -1.21 & $\begin{array}{l}+2.10 \\
-1.05 \\
+0.24\end{array}$ & $\begin{array}{l}-2.10 \\
+1.05 \\
-0.22 \\
\end{array}$ & +1.00 & +2.01 & \\
\hline Total & 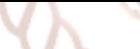 & 8 & & -43.84 & +43.86 & 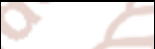 & & \\
\hline
\end{tabular}

\section{Mid Span of IJ}

Table 11: Maximum positive B.M at Mid Span of IJ

Positive B.M at Mid Span $=\frac{w l^{2}}{8}-\left(\frac{43.84+43.86}{2}\right)$

$$
\begin{aligned}
& =\frac{3}{2} \mathrm{x} 45.13-43.85 \\
& =23.84 \mathrm{KN}-\mathrm{m}
\end{aligned}
$$

\begin{tabular}{|c|c|c|c|c|c|c|c|c|}
\hline Joint & I & & $\bar{J}$ & & $\mathrm{~K}$ & & $\mathrm{~L}$ & \\
\hline Member & $\mathrm{IH}$ & IJ & JI & JK & $\mathrm{KJ}$ & $\mathrm{KL}$ & LK & LS \\
\hline $\begin{array}{l}\text { Distribution } \\
\text { factor }\end{array}$ & 0.11 & 0.11 & 0.11 & 0.11 & 0.11 & 0.11 & 0.28 & 0 \\
\hline $\begin{array}{l}\text { 1.D.L.F.E.M } \\
\text { 2.T.L.F.E.M }\end{array}$ & +43.66 & -26.85 & +26.85 & -43.66 & +43.66 & -26.35 & +26.35 & -5.59 \\
\hline $\begin{array}{l}\text { 3.Distribute } \\
\text { 4.carry over } \\
\text { 5.Distribute }\end{array}$ & & -1.84 & -0.92 & $\begin{array}{l}+1.84 \\
-0.95 \\
+0.20 \\
\end{array}$ & $\begin{array}{l}-1.90 \\
+0.92 \\
+0.21 \\
\end{array}$ & -2.90 & -5.81 & \\
\hline Total & & & & -42.57 & +42.89 & & & \\
\hline
\end{tabular}

\section{Mid Span of JK}

Table 12: Maximum positive B.M at Mid Span of JK 
International Journal of Trend in Scientific Research and Development (IJTSRD) ISSN: 2456-6470

Positive B.M at Mid Span $=\frac{w l^{2}}{8}-\left(\frac{42.57+4.89}{2}\right)$

$$
\begin{aligned}
& =\frac{3}{2} \mathrm{x} 43.66-42.73 \\
& =22.76 \mathrm{KN}-\mathrm{m}
\end{aligned}
$$

\begin{tabular}{|c|c|c|c|c|c|c|}
\hline Joint & \multicolumn{2}{|l|}{$\bar{J}$} & \multicolumn{2}{|l|}{$\mathrm{K}$} & \multicolumn{2}{|l|}{$\bar{L}$} \\
\hline Member & JI & $\mathrm{JK}$ & KJ & KL & LK & LS \\
\hline Distribution factor & 0.11 & 0.11 & 0.11 & 0.11 & 0.28 & 0 \\
\hline $\begin{array}{l}\text { 1.D.L.F.E.M } \\
\text { 2.T.L.F.E.M }\end{array}$ & +45.13 & -25.97 & +25.97 & -44.29 & +44.29 & -3.32 \\
\hline $\begin{array}{l}\text { 3.Distribute } \\
\text { 4.carry over } \\
\text { 5.Distribute }\end{array}$ & & -2.10 & -1.05 & $\begin{array}{l}+2.01 \\
-5.73 \\
+0.74 \\
\end{array}$ & $\begin{array}{l}-11.47 \\
+1.00 \\
-0.28 \\
\end{array}$ & \\
\hline Total & & 3 & & -47.27 & +33.54 & \\
\hline
\end{tabular}

\section{Mid Span of KL}

Table 13: Maximum positive B.M at Mid Span of KL

Positive B.M at Mid Span $=\frac{w l^{2}}{8}-\left(\frac{47.27+33.54}{2}\right)$

$$
=\frac{3}{2} \times 44.29-40.40
$$

\begin{tabular}{|c|c|c|c|c|c|c|c|c|c|c|c|}
\hline Joint & G & $\mathrm{H}$ & & \multicolumn{2}{|l|}{$\mathrm{I}$} & \multicolumn{2}{|l|}{$J$} & \multicolumn{2}{|l|}{$\mathrm{K}$} & \multicolumn{2}{|l|}{$\bar{L}$} \\
\hline $\begin{array}{l}\text { Distribution } \\
\text { factors for } \\
\text { Top } \\
\text { Bottom }\end{array}$ & $\begin{array}{l}0.36 \\
0.37\end{array}$ & $\begin{array}{l}3 \\
0.400 \\
0.40\end{array}$ & 9 & $\begin{array}{l}f \text { TreV } \\
0.39 \\
0.39 \\
D e\end{array}$ & earc & $\begin{array}{l}\text { sien' } \\
0.39 \\
0.39\end{array}$ & iic & $\begin{array}{l}0.39 \\
0.39\end{array}$ & & $\begin{array}{l}0.36 \\
0.36\end{array}$ & \\
\hline $\begin{array}{l}\text { Member } \\
\text { (beams) }\end{array}$ & $\mathrm{GH}$ & $\mathrm{HG}$ & $\mathrm{HI}$ & $\mathrm{IH}$ & IJ & $\mathrm{JI}$ & $\mathrm{JK}$ & $\mathrm{KJ}$ & $\mathrm{KL}$ & LK & $\mathrm{LS}$ \\
\hline $\begin{array}{l}\text { Distribution } \\
\text { factors }\end{array}$ & 0.27 & 0.10 & 0.10 & $0.11 \circlearrowleft$ & 0.11 & 0.11 & 0.11 & 0.11 & 0.11 & 0.28 & 0 \\
\hline $\begin{array}{l}\text { 1.T.L.F.E.M } \\
\text { 2.Distributio } \\
\text { n \& carry } \\
\text { over } \\
\text { 3.Add (1) \& } \\
\text { (2) }\end{array}$ & $\begin{array}{l}-50.36 \\
-1.21 \\
-51.57\end{array}$ & $\begin{array}{l}+50.36 \\
+6.79 \\
+57.15\end{array}$ & $\begin{array}{l}-25.97 \\
+1.05 \\
-24.92\end{array}$ & $\begin{array}{l}+25.97 \\
-1.21 \\
+24.92\end{array}$ & $\begin{array}{l}-45.13 \\
-1.05 \\
-46.18\end{array}$ & $\begin{array}{l}+45.13 \\
+1.05 \\
+46.18\end{array}$ & $\begin{array}{l}-25.97 \\
+1.00 \\
-24.97\end{array}$ & $\begin{array}{l}+25.97 \\
-1.05 \\
+24.92\end{array}$ & $\begin{array}{l}-44.29 \\
-5.73 \\
-50.02\end{array}$ & $\begin{array}{l}+44.29 \\
+1.00 \\
+45.29\end{array}$ & $\begin{array}{l}-3.32 \\
-3.32\end{array}$ \\
\hline $\begin{array}{l}\text { 4. Distribute } \\
\text { Top column } \\
\text { Bottom } \\
\text { column }\end{array}$ & $\begin{array}{l}+18.56 \\
+19.08\end{array}$ & $\begin{array}{l}-12.89 \\
-12.89\end{array}$ & & $\begin{array}{l}+8.35 \\
+8.35\end{array}$ & & $\begin{array}{l}-8.27 \\
-8.27\end{array}$ & & $\begin{array}{l}+9.78 \\
+9.78 \\
\end{array}$ & & $\begin{array}{l}-15.10 \\
-15.10 \\
\end{array}$ & \\
\hline
\end{tabular}

$=26.03 \mathrm{KN}-\mathrm{m}$

\section{Moment Distribution for maximum moments in columns}

Table 14: Maximum moments in columns for first loading condition

\begin{tabular}{|l|l|l|l|l|l|l|}
\hline Joint & G & H & I & J & K & L \\
\hline $\begin{array}{l}\text { Distribution } \\
\text { factors for }\end{array}$ & & & & & & \\
Top & 0.36 & 0.40 & 0.39 & 0.39 & 0.39 & 0.36 \\
Bottom & 0.37 & 0.40 & 0.39 & 0.39 & 0.39 & 0.36 \\
\hline
\end{tabular}


International Journal of Trend in Scientific Research and Development (IJTSRD) ISSN: 2456-6470

\begin{tabular}{|c|c|c|c|c|c|c|c|c|c|c|c|}
\hline $\begin{array}{l}\text { Member } \\
\text { (beams) }\end{array}$ & $\mathrm{GH}$ & $\mathrm{HG}$ & $\mathrm{HI}$ & $\mathrm{IH}$ & IJ & $\mathrm{JI}$ & $\mathrm{JK}$ & KJ & KL & LK & LS \\
\hline $\begin{array}{l}\text { Distribution } \\
\text { factors }\end{array}$ & 0.27 & 0.10 & 0.10 & 0.11 & 0.11 & 0.11 & 0.11 & 0.11 & 0.11 & 0.28 & 0 \\
\hline $\begin{array}{l}\text { 1.T.L.F.E.M } \\
\text { 2.Distributio } \\
\mathrm{n} \& \text { carry } \\
\text { over } \\
\text { 3.Add (1) \& } \\
\text { (2) }\end{array}$ & $\begin{array}{l}-29.95 \\
+0.68 \\
\\
-29.27\end{array}$ & $\begin{array}{l}+29.9 \\
5 \\
+4.04 \\
+33.9 \\
9\end{array}$ & $\begin{array}{l}-43.66 \\
-0.92 \\
-44.58\end{array}$ & $\begin{array}{l}+43.6 \\
6 \\
+0.68 \\
+44.3 \\
4\end{array}$ & $\begin{array}{l}-26.85 \\
+0.92 \\
\\
-25.93\end{array}$ & $\begin{array}{l}+26.8 \\
5 \\
-0.92 \\
+25.9 \\
3\end{array}$ & $\begin{array}{l}-43.66 \\
-0.95 \\
-44.61\end{array}$ & $\begin{array}{l}+43.6 \\
6 \\
+0.92 \\
+44.5 \\
8\end{array}$ & $\begin{array}{l}-26.35 \\
-2.90 \\
-29.25\end{array}$ & $\begin{array}{l}+26.3 \\
5 \\
-0.95 \\
+25.4\end{array}$ & $\begin{array}{l}-5.59 \\
-5.59\end{array}$ \\
\hline $\begin{array}{l}\text { 4.Distribute } \\
\text { Top column } \\
\text { Bottom } \\
\text { column }\end{array}$ & $\begin{array}{l}+10.5 \\
3 \\
+10.8 \\
2\end{array}$ & $\begin{array}{l}+4.23 \\
+4.23\end{array}$ & & $\begin{array}{l}-7.17 \\
-7.17\end{array}$ & & $\begin{array}{l}+7.28 \\
+7.28\end{array}$ & & $\begin{array}{l}-5.97 \\
-5.97\end{array}$ & & $\begin{array}{l}-7.13 \\
-7.13\end{array}$ & \\
\hline
\end{tabular}

Table 15: Maximum moments in columns for second loading condition

\section{Axial force calculation for first loading condition}

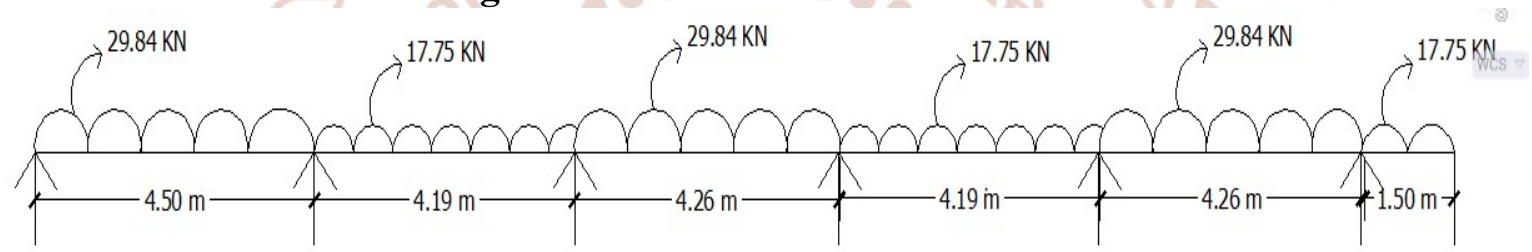

Figure 7: Axial force calculation
At $K$
$\mathrm{R}_{\mathrm{G}}+\mathrm{R}_{\mathrm{H}}+\mathrm{R}_{\mathrm{I}}+\mathrm{R}_{\mathrm{J}}+\mathrm{R}_{\mathrm{K}}+\mathrm{R}_{\mathrm{L}}=29.84 \times 4.50+$

$\mathrm{R}_{\mathrm{L}} \mathrm{X} 4.22-17.75 \times 1.50 \times 4.97$

$17.75 \times 4.19+29.84 \times 4.26+17.75 \times 4.19+29.84 \times 4.22$

$+9.78$

$\mathrm{R}_{\mathrm{L}}=96.63 \mathrm{KN}$

$+17.75 \times 1.50$

$\mathrm{R}_{\mathrm{G}}=100.27 \mathrm{KN}$

At J

$\mathrm{R}_{\mathrm{L}} \times 8.41+\mathrm{R}_{\mathrm{K}} \times 4.19-17.75 \times 1.50 \times 9.16$

$29.84 \times 4.22 \times 6.3-17.75 \times 4.19 \times 2.09=-8.27$

$\mathrm{R}_{\mathrm{K}}=88.71 \mathrm{KN}$

At I

$\mathrm{R}_{\mathrm{L}} \times 12.67+\mathrm{R}_{\mathrm{K}} \times 8.45+\mathrm{R}_{\mathrm{J}} \times 4.26-17.75 \times 1.50 \times 13.42-$

$29.84 \times 4.22 \times 10.56 \quad-17.75 \times 4.19 \times 6.35$

$29.84 \times 4.26 \times 2.13=+8.35$

$\mathrm{R}_{\mathrm{J}}=109 \mathrm{KN}$

At $\mathbf{H}$

$\mathrm{R}_{\mathrm{L}} \times 16.86+\mathrm{R}_{\mathrm{K}} \mathrm{X} 12.64+\mathrm{R}_{\mathrm{J}} \mathrm{X} 8.45+\mathrm{R}_{\mathrm{I}} \mathrm{X} 4.19-$

$17.75 \times 4.19 \times 2.09 \quad-\quad 29.84 \times 4.26 \times 6.32$

$17.75 \times 4.19 \times 10.54 \quad-\quad 29.84 \times 4.22 \times 14.75$

$17.75 \times 1.50 \times 17.61=-12.89$

$\mathrm{R}_{\mathrm{I}}=90.45 \mathrm{KN}$

At $\mathbf{G}$

$\mathrm{R}_{\mathrm{L}} \mathrm{x} 21.36+\mathrm{R}_{\mathrm{K}} \mathrm{x} 17.14+\mathrm{R}_{\mathrm{J}} \mathrm{12.95}+\mathrm{R}_{\mathrm{I}} \mathrm{X} 8.69+$

$\mathrm{R}_{\mathrm{H}} \mathrm{X} 4.50-17.75 \times 1.50 \times 16.02-29.84 \times 4.22 \times 19.25-$

$17.75 \times 4.19 \times 15.09-29.84 \times 4.26 \times 10.82$

$17.75 \times 4.19 \times 6.59-29.84 \times 4.50 \times 2.25=+18.56$

$\mathrm{R}_{\mathrm{H}}=77.63 \mathrm{KN}$

\subsection{Design of building components}

\subsubsection{Design of slab}

Slabs are plane structural members forming floors and roofs of building whose thickness is quite small compared to their other dimensions.

When the ratio of the length to the width of a slab is more then 2, and then most of the load is carried by shorter span and in such a case is known as one-way in case the ratio is less than 2 then it is called a twoway slab.

\section{Slab design}

1. Data

Effective span $=4.19 \mathrm{~m}$

$$
\begin{aligned}
& \text { Live load }=3 \mathrm{KN} / \mathrm{m}^{2} \\
& \mathrm{f}_{\text {ck }}=20 \mathrm{~N} / \mathrm{mm}^{2} \\
& \mathrm{f}_{\mathrm{y}}=415 \mathrm{~N} / \mathrm{mm}^{2}
\end{aligned}
$$

2. Thickness of slab

Adopt thickness of slab $=150 \mathrm{~mm}$

$$
\mathrm{D}=150 \mathrm{~mm}
$$




\section{Loads}

$$
\mathrm{d}=\mathrm{D}-20-\frac{10}{2}=150-20-5=125 \mathrm{~mm}
$$

Self weight of slab $=0.15 \times 25=3.75 \mathrm{KN} / \mathrm{m}^{2}$

Live load $=3 \mathrm{KN} / \mathrm{m}^{2}$

Floor finish $=1 \mathrm{KN} / \mathrm{m}^{2}$

Total load $=7.75 \mathrm{KN} / \mathrm{m}^{2}$

Factor loaded $w_{u}=1.5 \times 7.75=11.625 \mathrm{KN} / \mathrm{m}^{2}$

\section{Factored bending moment}

$$
\begin{aligned}
\mathrm{M}_{\mathrm{u}} & =\frac{\mathrm{w}_{\mathrm{u}} \mathrm{I}^{2}}{8} \\
= & \frac{11.625 x(4.191)^{2}}{8} \\
& =25.52 \mathrm{KN}-\mathrm{m}
\end{aligned}
$$

\section{Minimum depth required}

$$
\begin{aligned}
\mathrm{d}=\sqrt{\frac{\mathrm{M}_{\mathrm{u}}}{\frac{\mathrm{u}_{\mathrm{u}}}{0.138 \times \mathrm{f}_{\mathrm{ck}} \mathrm{xb}}}} & 0.138 \mathrm{f}_{\mathrm{ck}} \mathrm{bd}^{2} \\
& =\sqrt{\frac{25.52 \times 10^{6}}{0.138 \times 20 \times 100}} \\
& =96.15 \mathrm{~mm}<125 \mathrm{~mm}, \text { provided depth }
\end{aligned}
$$

Hence provided depth is adequate

\section{Tension reinforcement}

$$
\begin{aligned}
& \mathrm{M}_{\mathrm{u}}=0.87 \mathrm{f}_{\mathrm{y}} \mathrm{A}_{\mathrm{st}} \mathrm{d}\left[1-\frac{\mathrm{f}_{\mathrm{y}} \mathrm{A}_{\mathrm{st}}}{\mathrm{f}_{\mathrm{ck}} \mathrm{bd}}\right] \text { Internatio } \\
& 25.52 \times 10^{6}=0.87 \times 415 \times A_{s t} \times 125[1-
\end{aligned}
$$$$
\frac{415 \times A_{\text {st }}}{20 \times 1000 \times 25}
$$$$
A_{\mathrm{st}}=631.70 \mathrm{~mm}^{2}
$$

Minimum reinforcement $=0.12$ of gross area

$$
\begin{aligned}
& =\frac{0.12}{100} \times 1000 \times 150 \\
& =180 \mathrm{~mm}^{2}
\end{aligned}
$$

$A_{\text {st }}>A_{\text {st,min }}$ Hence ok

Using $10 \mathrm{~mm} \Phi$ bars, spacing of bars $\mathrm{S}=\frac{1000 \mathrm{xa}_{\mathrm{st}}}{\mathrm{A}_{\mathrm{st}}}$

$$
\begin{aligned}
= & \frac{\Pi_{4} \times 10^{2} \times 1000}{631.70}=124.3 \mathrm{~mm} \\
= & 125 \mathrm{~mm}
\end{aligned}
$$

Maximum spacing is

$$
\begin{array}{ll}
\text { i. } & 3 \mathrm{~d}=3 \times 125=375 \mathrm{~mm} \\
\text { ii. } & 300 \mathrm{~mm} \text { which ever is less }
\end{array}
$$

Hence provide $10 \mathrm{~mm} \Phi$ bars at $125 \mathrm{~mm} \mathrm{c} / \mathrm{c}$

\section{Distribution reinforcement}

$$
\begin{aligned}
\mathrm{A}_{\mathrm{st}} & =0.12 \% \text { of gross area } \\
& =\frac{0.12}{100} \times 1000 \times 150=180 \mathrm{~mm}^{2}
\end{aligned}
$$

Using $8 \mathrm{~mm} \Phi$ bars, spacing of bars

$$
\begin{aligned}
\mathrm{S} & =\frac{\frac{\pi}{4} \times 8^{2} \times 1000}{180}=279.2 \mathrm{~mm} \\
& =280 \mathrm{~mm}
\end{aligned}
$$

Maximum spacing is

$$
\begin{array}{ll}
\text { i. } & 5 \mathrm{~d}=5 \times 125=625 \mathrm{~mm} \\
\text { ii. } & 450 \mathrm{~mm} \text { whichever is less }
\end{array}
$$

Hence provide $8 \mathrm{~mm} \Phi$ bars at $280 \mathrm{~mm} \mathrm{c} / \mathrm{c}$

\subsection{2: Design of Beam}

1. Beam is a member which transfers the loads from slab to columns and then foundation to soil.

2. Beam is a tension member.

3. Span of slabs, which decide the spacing of beams.

4. The designing of the beam mainly consists of fixing the breadth and depth of the beam and arriving at the area of steel and the diameter of bars to be used.

1. Data

$\mathrm{b}=230 \mathrm{~mm}$

$\mathrm{D}=460 \mathrm{~mm}$

$\mathrm{d}=430 \mathrm{~mm}$

$$
\begin{aligned}
& \mathrm{f}_{\mathrm{ck}}=20 \mathrm{~N} / \mathrm{mm}^{2} \\
& \mathrm{f}_{\mathrm{y}}=415 \mathrm{~N} / \mathrm{mm}^{2}
\end{aligned}
$$

\section{Depth required}

The minimum depth required to resist the bending moment

$$
\begin{aligned}
& \mathrm{M}_{\mathrm{u}}=\mathrm{M}_{\mathrm{u}, \mathrm{lim}} \\
& \mathrm{M}_{\mathrm{u}}=0.138 \mathrm{f}_{\mathrm{ck}} \mathrm{bd}^{2}
\end{aligned}
$$

$55.90 \times 10^{6}=0.138 \times 20 \times 230 \times d^{2}$

$\mathrm{d}=296.74 \mathrm{~mm}<430 \mathrm{~mm}$, provided depth

Hence provided depth is adequate

\begin{tabular}{|l|l|}
\hline Joint & Support moment \\
\hline G & -37.65 \\
\hline H & -55.90 \\
\hline I & -45.98 \\
\hline J & -46.01 \\
\hline K & -49.43 \\
\hline L & -34.18 \\
\hline
\end{tabular}

Table 16: Support moments

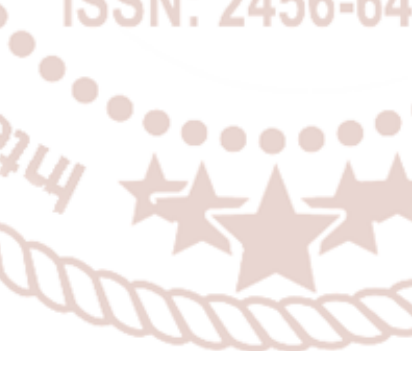

\begin{tabular}{|l|l|}
\hline Span & Span moment \\
\hline GH & +29.74 \\
\hline HI & +22.56 \\
\hline IJ & +23.84 \\
\hline JK & +22.76 \\
\hline KL & +26.03 \\
\hline
\end{tabular}

Table-17: Span moments

\section{Reinforcement at supports}

At joint $\mathrm{G}, \mathrm{M}_{\mathrm{u}}=-37.65 \mathrm{KN}-\mathrm{m}$

$\mathrm{M}_{\mathrm{u}}=0.87 \mathrm{f}_{\mathrm{y}} \mathrm{A}_{\mathrm{st}} \mathrm{d}\left[1-\frac{\mathrm{f}_{\mathrm{y}} \mathrm{A}_{\mathrm{st}}}{\mathrm{f}_{\mathrm{ckb}}}\right]$

$37.65 \times 10^{6}=0.87 \times 415 \times A_{s t} \times 430\left[1-\frac{415 \times A_{s t}}{20 \times 230 \times 430}\right]$

$\mathrm{A}_{\text {st }}=256.22 \mathrm{~mm}^{2}$

Provide 3-12 mm $\Phi$ bars (339.29 $\mathrm{mm}^{2}$ )

At joint $\mathrm{H}, \mathrm{M}_{\mathrm{u}}=-55.90 \mathrm{KN}-\mathrm{m}$

$\mathrm{M}_{\mathrm{u}}=0.87 \mathrm{f}_{\mathrm{y}} \mathrm{A}_{\mathrm{st}} \mathrm{d}\left[1-\frac{\mathrm{f}_{\mathrm{y}} \mathrm{A}_{\mathrm{st}}}{\mathrm{f}_{\mathrm{ck}}}\right]$ 
$55.90 \times 10^{6}=0.87 \times 415 \times A_{\text {st }} \times 430\left[1-\frac{415 \times A_{s t}}{20 \times 230 \times 43}\right]$

$\mathrm{A}_{\mathrm{st}}=392.12 \mathrm{~mm}^{2}$

Provide 2-16 mm $\Phi$ bars $\left(402.12 \mathrm{~mm}^{2}\right)$

At joint $\mathrm{I}, \mathrm{M}_{\mathrm{u}}=-45.98 \mathrm{KN}-\mathrm{m}$

$\mathrm{M}_{\mathrm{u}}=0.87 \mathrm{f}_{\mathrm{y}} \mathrm{A}_{\mathrm{st}} \mathrm{d}\left[1-\frac{\mathrm{f}_{\mathrm{y}} \mathrm{A}_{\mathrm{st}}}{\mathrm{f}_{\mathrm{ckb}}}\right]$

$45.98 \times 10^{6}=0.87 \times 415 \times A_{s t} \times 430\left[1-\frac{415 \times A_{s t}}{20 \times 230 \times 430}\right]$

$\mathrm{A}_{\mathrm{st}}=317.18 \mathrm{~mm}^{2}$

Provide 2-16 $\mathrm{mm} \Phi$ bars $\left(402.12 \mathrm{~mm}^{2}\right)$

At joint $\mathrm{J}, \mathrm{M}_{\mathrm{u}}=-46.01 \mathrm{KN}-\mathrm{m}$

$\mathrm{M}_{\mathrm{u}}=0.87 \mathrm{f}_{\mathrm{y}} \mathrm{A}_{\mathrm{st}} \mathrm{d}\left[1-\frac{\mathrm{f}_{\mathrm{y}} \mathrm{A}_{\mathrm{st}}}{\mathrm{f}_{\mathrm{ckb}}}\right]$

$46.01 \times 10^{6}=0.87 \times 415 \times A_{s t} \times 430\left[1-\frac{415 \times A_{s t}}{20 \times 230 \times 430}\right]$

$\mathrm{A}_{\mathrm{st}}=317.40 \mathrm{~mm}^{2}$

Provide 2-16 mm $\Phi$ bars $\left(402.12 \mathrm{~mm}^{2}\right)$

At joint $\mathrm{K}, \mathrm{M}_{\mathrm{u}}=-49.43 \mathrm{KN}-\mathrm{m}$

$\mathrm{M}_{\mathrm{u}}=0.87 \mathrm{f}_{\mathrm{y}} \mathrm{A}_{\mathrm{st}} \mathrm{d}\left[1-\frac{\mathrm{f}_{\mathrm{y}} \mathrm{A}_{\mathrm{st}}}{\mathrm{f}_{\mathrm{ckb}}}\right]$

$49.43 \times 10^{6}=0.87 \times 415 \times A_{\text {st }} \times 430\left[1-\frac{415 \times A_{s t}}{20 \times 230 \times 43}\right]$

$\mathrm{A}_{\mathrm{st}}=342.96 \mathrm{~mm}^{2}$

Provide 2-16 mm $\Phi$ bars $\left(402.12 \mathrm{~mm}^{2}\right)$

At joint $\mathrm{L}, \mathrm{M}_{\mathrm{u}}=-34.18 \mathrm{KN}-\mathrm{m}$

$\mathrm{M}_{\mathrm{u}}=0.87 \mathrm{f}_{\mathrm{y}} \mathrm{A}_{\mathrm{st}} \mathrm{d}\left[1-\frac{\mathrm{f}_{\mathrm{y}} \mathrm{A}_{\mathrm{st}}}{\mathrm{f}_{\mathrm{ckb}_{\mathrm{d}}}}\right]$

$34.18 \times 10^{6}=0.87 \times 415 \times A_{s t} \times 430\left[1-\frac{415 \times A_{\text {st }}}{20 \times 230 \times 430}\right]$

$\mathrm{A}_{\mathrm{st}}=231.33 \mathrm{~mm}^{2}$

Provide 3-12 mm $\Phi$ bars $\left(339.29 \mathrm{~mm}^{2}\right.$ )

\section{Reinforcement at mid spans}

At mid span of $\mathrm{GH}, \mathrm{M}_{\mathrm{u}}=+29.74 \mathrm{KN}-\mathrm{m}$

$\mathrm{M}_{\mathrm{u}}=0.87 \mathrm{f}_{\mathrm{y}} \mathrm{A}_{\mathrm{st}} \mathrm{d}\left[1-\frac{\mathrm{f}_{\mathrm{y}} \mathrm{A}_{\mathrm{st}}}{\mathrm{f}_{\mathrm{ckb}}}\right]$

$29.74 \times 10^{6}=0.87 \times 415 \times A_{s t} \times 430\left[1-\frac{415 \times A_{s t}}{20 \times 230 \times 430}\right]$

$\mathrm{A}_{\mathrm{st}}=199.91 \mathrm{~mm}^{2}$

Provide 2-12 $\mathrm{mm} \Phi$ bars $\left(226.19 \mathrm{~mm}^{2}\right)$

At mid span of $\mathrm{HI}, \mathrm{M}_{\mathrm{u}}=+22.56 \mathrm{KN}-\mathrm{m}$

$\mathrm{M}_{\mathrm{u}}=0.87 \mathrm{f}_{\mathrm{y}} \mathrm{A}_{\mathrm{st}} \mathrm{d}\left[1-\frac{\mathrm{f}_{\mathrm{y}} \mathrm{A}_{\mathrm{st}}}{\mathrm{f}_{\mathrm{ckb}}}\right]$

$22.56 \times 10^{6}=0.87 \times 415 \times A_{s t} \times 430\left[1-\frac{415 \times A_{s t}}{20 \times 230 \times 430}\right]$

$\mathrm{A}_{\mathrm{st}}=150.01 \mathrm{~mm}^{2}$

Provide 2-12 $\mathrm{mm} \Phi$ bars $\left(226.19 \mathrm{~mm}^{2}\right)$

At mid span of IJ, $\mathrm{M}_{\mathrm{u}}=+23.84 \mathrm{KN}-\mathrm{m}$

$\mathrm{M}_{\mathrm{u}}=0.87 \mathrm{f}_{\mathrm{y}} \mathrm{A}_{\mathrm{st}} \mathrm{d}\left[1-\frac{\mathrm{f}_{\mathrm{y}} \mathrm{A}_{\mathrm{st}}}{\mathrm{f}_{\mathrm{ckb}}}\right]$

$23.84 \times 10^{6}=0.87 \times 415 \times A_{s t} \times 430\left[1-\frac{415 \times A_{s t}}{20 \times 230 \times 430}\right]$

$\mathrm{A}_{\mathrm{st}}=158.82 \mathrm{~mm}^{2}$

Provide 2-12 $\mathrm{mm} \Phi$ bars $\left(226.19 \mathrm{~mm}^{2}\right)$
At mid span of JK, $\mathrm{M}_{\mathrm{u}}=+22.76 \mathrm{KN}-\mathrm{m}$

$\mathrm{M}_{\mathrm{u}}=0.87 \mathrm{f}_{\mathrm{y}} \mathrm{A}_{\mathrm{st}} \mathrm{d}\left[1-\frac{\mathrm{f}_{\mathrm{y}} \mathrm{A}_{\mathrm{st}}}{\mathrm{f}_{\mathrm{ckb}_{\mathrm{d}}}}\right]$

$22.76 \times 10^{6}=0.87 \times 415 \times A_{s t} \times 430\left[1-\frac{415 \times A_{s t}}{20 \times 230 \times 430}\right]$

$\mathrm{A}_{\mathrm{st}}=151.39 \mathrm{~mm}^{2}$

Provide 2-12 $\mathrm{mm} \Phi$ bars $\left(226.19 \mathrm{~mm}^{2}\right.$ )

At mid span of KL, $\mathrm{M}_{\mathrm{u}}=+26.03 \mathrm{KN}-\mathrm{m}$

$\mathrm{M}_{\mathrm{u}}=0.87 \mathrm{f}_{\mathrm{y}} \mathrm{A}_{\mathrm{st}} \mathrm{d}\left[1-\frac{\mathrm{f}_{\mathrm{y}} \mathrm{A}_{\mathrm{st}}}{\mathrm{f}_{\mathrm{ckb}_{\mathrm{d}}}}\right]$

$26.03 \times 10^{6}=0.87 \times 415 \times A_{s t} \times 430\left[1-\frac{415 \times A_{s t}}{20 \times 230 \times 430}\right]$

$\mathrm{A}_{\mathrm{st}}=173.98 \mathrm{~mm}^{2}$

Provide 2-12 $\mathrm{mm} \Phi$ bars $\left(226.19 \mathrm{~mm}^{2}\right)$

\section{Shear reinforcement}

Effective $\operatorname{span}=4.23 \mathrm{~m}$

Factored fixed load $\mathrm{w}_{\mathrm{ud}}=1.5 \mathrm{x}(15.11+2.64)$

$$
=26.63 \mathrm{KN} / \mathrm{m}
$$

Factored load, not fixed $\mathrm{w}_{\mathrm{ul}}=1.5 \times 12.09=18.13$ $\mathrm{KN} / \mathrm{m}$

Shear force at the section $\mathrm{V}_{\mathrm{u}}=0.6 \mathrm{w}_{\mathrm{ud}} 1+0.6 \mathrm{w}_{\mathrm{ul}} 1$

$=0.6 \times 26.63 \times 4.23+0.6 \times 18.13 \times 4.23$

$=113.60 \mathrm{KN}$

Nominal shear stress $\tau_{\mathrm{v}}=\frac{\mathrm{V}_{\mathrm{u}}}{\mathrm{bd}}$

$$
\begin{aligned}
= & \frac{113.60 \times 10^{3}}{230 \times 430} \\
= & 1.14 \mathrm{~N} / \mathrm{mm}^{2}
\end{aligned}
$$

Percentage of tension steel at support

$$
\begin{aligned}
\mathrm{P}_{\mathrm{t}} & =\frac{\mathrm{A}_{\mathrm{st}} \times 100}{\mathrm{bd}} \\
& =\frac{339.29 \times 10}{230 \times 430}=0.34 \%
\end{aligned}
$$

Referring to the table-19 of IS: 456 . Shear strength of concrete is

$\tau_{\mathrm{c}}=0.40 \mathrm{~N} / \mathrm{mm}^{2}$

Maximum shear stress in concrete $\tau_{c, \text { max }}$ from table20 of IS: 456

$\tau_{\mathrm{c}, \max }=2.8 \mathrm{~N} / \mathrm{mm}^{2}$

As $\tau_{v}>\tau_{c}$, shear reinforcement has to be designed

Shear resistance of concrete

$\mathrm{V}_{\mathrm{uc}}=\tau_{\mathrm{c}} \mathrm{bd}=0.40 \times 230 \times 430$

$=39560 \mathrm{~N}=39.56 \mathrm{KN}$

Shear to be resisted by shear reinforcement (vertical stirrups)

$\mathrm{V}_{\mathrm{us}}=\mathrm{V}_{\mathrm{u}}-\mathrm{V}_{\mathrm{uc}}$

$=113.60-39.56=74.04 \mathrm{KN}$

Using $8 \mathrm{~mm}, 2$ legged $\mathrm{f}_{\mathrm{y}} 415$ steel stirrups

$\mathrm{A}_{\mathrm{sv}}=2 \mathrm{x} \frac{\pi}{4} \mathrm{x} 8^{2}=100.5 \mathrm{~mm}^{2}$

$\mathrm{S}_{\mathrm{v}}=\frac{0.87 \mathrm{f}_{\mathrm{y}} \mathrm{A}_{\mathrm{sv}} \mathrm{d}}{\mathrm{V}_{\mathrm{us}}}$

$=\frac{0.87 \times 415 \times 100.5 \times 430}{74040}=210 \mathrm{~mm}$

Hence, provide2 legged $8 \mathrm{~mm}$ stirrups at $210 \mathrm{~mm} \mathrm{c} / \mathrm{c}$ 


\subsubsection{Design of column}

\section{Data}

$\mathrm{b}=230 \mathrm{~mm}$

$\mathrm{D}=460 \mathrm{~mm}$

$\mathrm{f}_{\mathrm{ck}}=20 \mathrm{~N} / \mathrm{mm}^{2}$

$\mathrm{f}_{\mathrm{y}}=415 \mathrm{~N} / \mathrm{mm}^{2}$

Factored load $\mathrm{P}_{\mathrm{u}}=100.27 \times 1.5$

$$
=150 \mathrm{KN}
$$

Factored moment $\mathrm{M}_{\mathrm{u}}=37.12 \times 1.5$

$$
=55.68 \mathrm{KN}-\mathrm{m}
$$

Assuming effective cover $\mathrm{d}^{\prime}=60 \mathrm{~mm}$ $\frac{\mathrm{d}^{\prime}}{\mathrm{D}}=\frac{60}{460}=0.13 \approx 0.15$

\section{Non Dimensional Parameters}

$$
\begin{aligned}
\mathrm{p}_{\mathrm{u}} & =\frac{\mathrm{P}_{\mathrm{u}}}{\mathrm{f}_{\mathrm{ck}} \mathrm{bD}} \\
& =\frac{150 \mathrm{x} \quad{ }^{3}}{20 \times 230 \times 460} \\
& =0.070 . \\
\mathrm{m}_{\mathrm{u}} & =\frac{\mathrm{M}_{\mathrm{u}}}{\mathrm{f}_{\mathrm{ck} \mathrm{bD}^{2}}} \\
& =\frac{55.68 \mathrm{x} 1{ }^{6}}{20 \times 230 \times 460^{2}} \\
& =0.057 \approx 0.06
\end{aligned}
$$

\section{Longitudinal reinforcement}

Referring to chart $33\left(d^{\prime} /{ }_{D}=0.15\right.$ ) of SP: 16 it can

be observed that, the coordinates $\mathrm{p}_{\mathrm{u}}=0.070, \mathrm{~m}_{\mathrm{u}}=0.06$

would lie on a design interaction curve with

$$
\begin{aligned}
\mathrm{P}_{\text {req }} & =0.03 \times 20 \\
& =0.6
\end{aligned}
$$

$\mathrm{A}_{\text {st, req }}=0.6 \times 230 \times 460 / 100$

$$
=634.8 \mathrm{~mm}^{2}
$$

Provide 6-12 $\mathrm{mm} \Phi$ bars

\section{Lateral ties}

$$
\frac{\mathrm{p}}{\mathrm{f}_{\mathrm{ck}}} \approx 0.03
$$

Using $8 \mathrm{~mm} \Phi$ ties, spacing is least of the following

i. Least lateral dimension $=230 \mathrm{~mm}$

ii. $16 \mathrm{~d}=16 \times 12=192 \mathrm{~mm}$

iii. $\quad 300 \mathrm{~mm}$

Provide 6-12 $\mathrm{mm} \Phi$ bars at $200 \mathrm{~mm} \mathrm{c} / \mathrm{c}$

\subsubsection{Design of stair case}

\section{Proportioning of stairs}

Dimension of hall $=3.04 \times 5.79 \mathrm{~m}$

Height of floor $=3.840 \mathrm{~m}$

Height of flight $=2.133 \mathrm{~m}$

Rise $=150 \mathrm{~mm}$

Thread $=300 \mathrm{~mm}$
Number of rises $=\frac{2133}{150}=14.22$

No of rises $=14$

No of treads $=14-1=13$

For 13 treads, the length required $=10 \times 0.30=3 \mathrm{~m}$

\section{Effective span}

Effective span $=5.791+0.115$

$=5.906 \mathrm{~m}$

\section{Thickness of slab}

Assume effective depth

$\mathrm{d}=\frac{\text { span }}{25}=\frac{5906}{25}=236.24 \mathrm{~mm}$

$\mathrm{d}=240 \mathrm{~mm}$ and $\mathrm{D}=270 \mathrm{~mm}$

\section{Loads}

Loads per meter horizontal width of stairs are as follows

Weight of waist slab $=\mathrm{D} \sqrt{1+\left(\frac{\mathrm{R}}{\mathrm{T}}\right)^{2}} \times 25$

$$
\begin{aligned}
& =0.27 \mathrm{x} \sqrt{1+\left(\frac{0.15}{0.300}\right)^{2}} \times 25 \\
& =7.546 \mathrm{KN} / \mathrm{m}
\end{aligned}
$$

Live load $=3 \mathrm{KN} / \mathrm{m}^{2}$

Floor finish $=0.63 \mathrm{KN} / \mathrm{m}^{2}$

Total load $=13.0213 \mathrm{KN} / \mathrm{m}^{2}$

Factored load $=1.5 \times 13.021=19.531 \mathrm{KN} / \mathrm{m}$

\section{Factored bending moment}

$$
\begin{aligned}
\mathrm{M}_{\mathrm{u}} & =\frac{\mathrm{w}_{\mathrm{u}} \mathrm{l}^{2}}{8} \\
& =\frac{19.53(5.90)^{2}}{8} \\
& =84.97 \mathrm{KN}-\mathrm{m} \\
& =84.97 \times 10^{6} \mathrm{~N}-\mathrm{mm}
\end{aligned}
$$

\section{Minimum depth required}

The minimum depth required to resist bending moment

$\mathrm{M}_{\mathrm{u}}=0.138 \mathrm{f}_{\mathrm{ck}} \mathrm{bd}^{2}$

$$
\begin{aligned}
\mathrm{d} & =\sqrt{\frac{\mathrm{M}}{0.138 \mathrm{xf}_{\mathrm{ck}} \mathrm{xb}}} \\
& =\sqrt{\frac{84.97 \times 10^{6}}{0.138 \times 20 \times 100}}
\end{aligned}
$$

$=175.46 \mathrm{~mm}<240 \mathrm{~mm}$, provide depth

Hence provided depth is adequate

\section{Tension reinforcement}

$\mathrm{M}_{\mathrm{u}}=0.87 \mathrm{f}_{\mathrm{y}} \mathrm{A}_{\mathrm{st}} \mathrm{d}\left[1-\frac{\mathrm{f}_{\mathrm{y}} \mathrm{A}_{\mathrm{st}}}{\mathrm{f}_{\mathrm{ck}}}\right]$

$84.97 \times 10^{6}=0.87 \times 415 \times A_{s t} \times 240\left[1-\frac{415 \times A_{s t}}{20 \times 1000 \times 2}\right\rfloor$ 
$\mathrm{A}_{\mathrm{st}}=1081.74 \mathrm{~mm}^{2}$

Using $12 \mathrm{~mm} \Phi$ bars, spacing of bars

$$
\begin{aligned}
\mathrm{S} & =\frac{1000 \mathrm{x}_{\text {st }}}{\mathrm{A}_{\text {st }}} \\
& =\frac{\frac{\pi}{4} \times 12^{2} \times 100}{1081} \\
& =104.6 \mathrm{~mm}
\end{aligned}
$$

Hence provide $12 \mathrm{~mm} \Phi$ bars at $100 \mathrm{~mm} \mathrm{c/c}$

\section{Distribution reinforcement}

$$
\begin{aligned}
A_{\text {st }} & =0.12 \% \text { of gross area } \\
& =\frac{0.12}{100} \times 1000 \times 270 \\
& =324 \mathrm{~mm}^{2}
\end{aligned}
$$

Using $8 \mathrm{~mm}$ bars, spacing of bars

$$
\begin{aligned}
\mathrm{S} & =\frac{\frac{\pi}{4} \times 8^{2} \times 1000}{324} \\
& =155.1 \mathrm{~mm}
\end{aligned}
$$

Hence provide $8 \mathrm{~mm} \Phi$ bars at $150 \mathrm{~mm} \mathrm{c} / \mathrm{c}$

\section{CHAPTER-5 DRAWINGS}

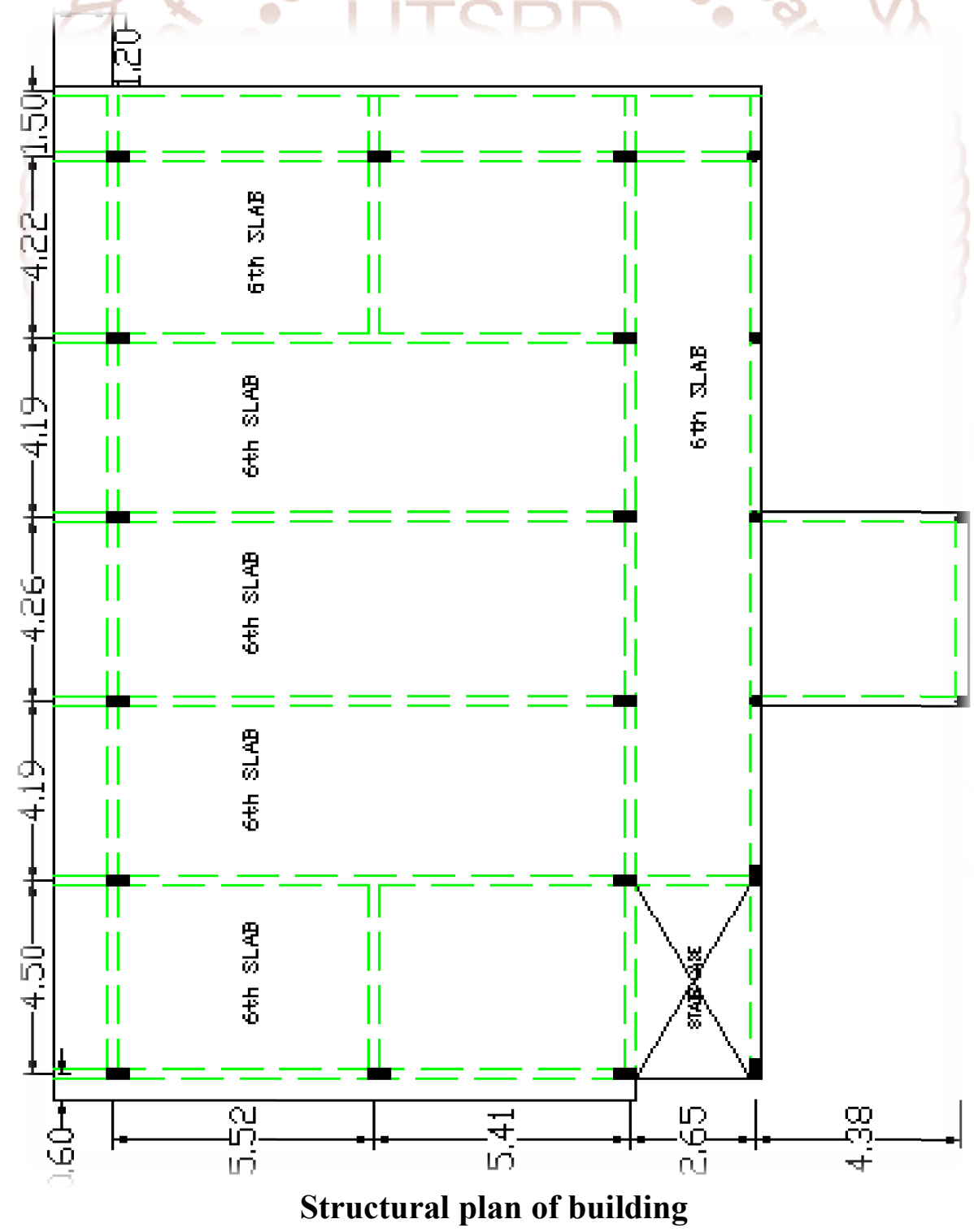



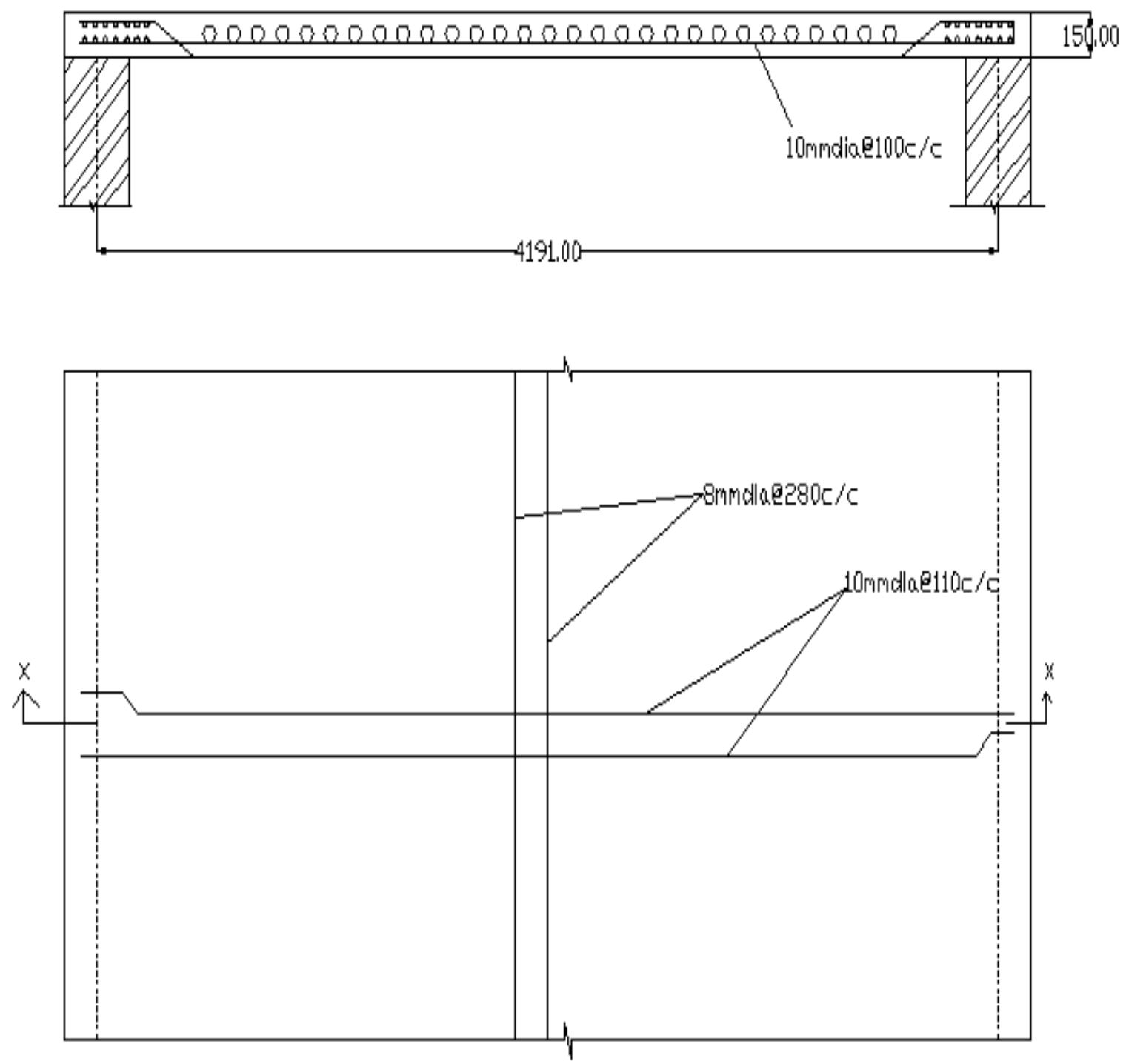

\section{Details of Reinforcement in One-way slab}

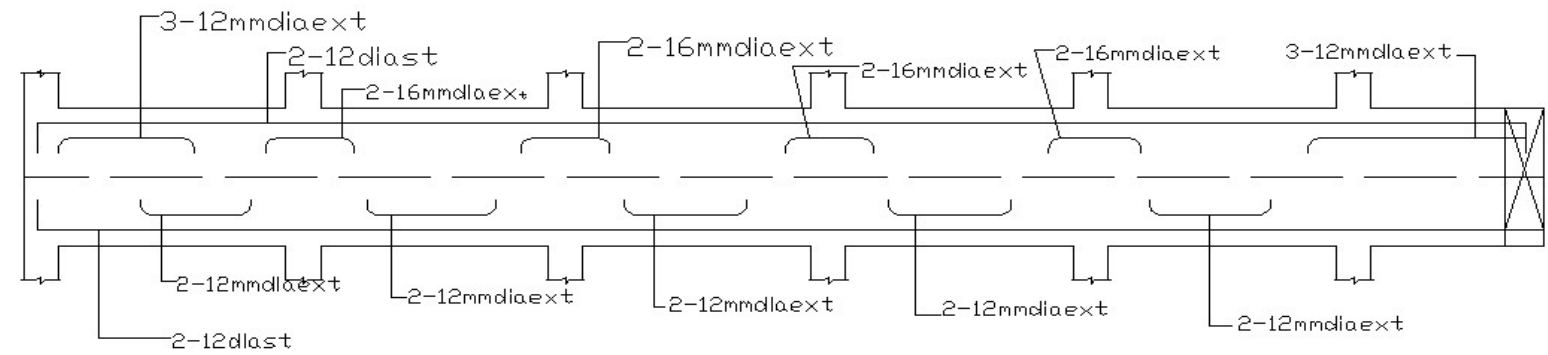


International Journal of Trend in Scientific Research and Development (IJTSRD) ISSN: 2456-6470

\section{Details of Reinforcement in Beam}

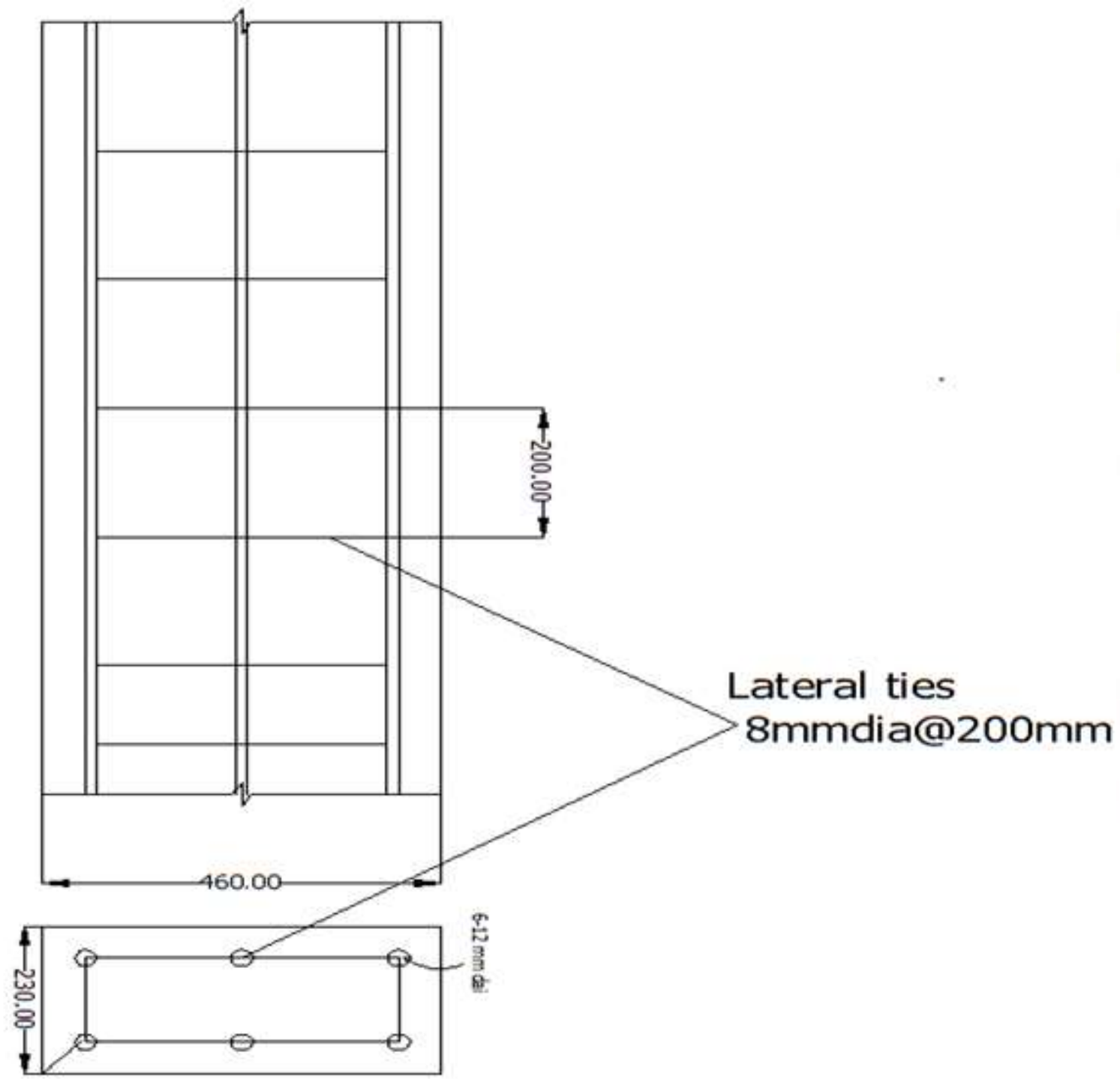

Details of Rein forcement in Column

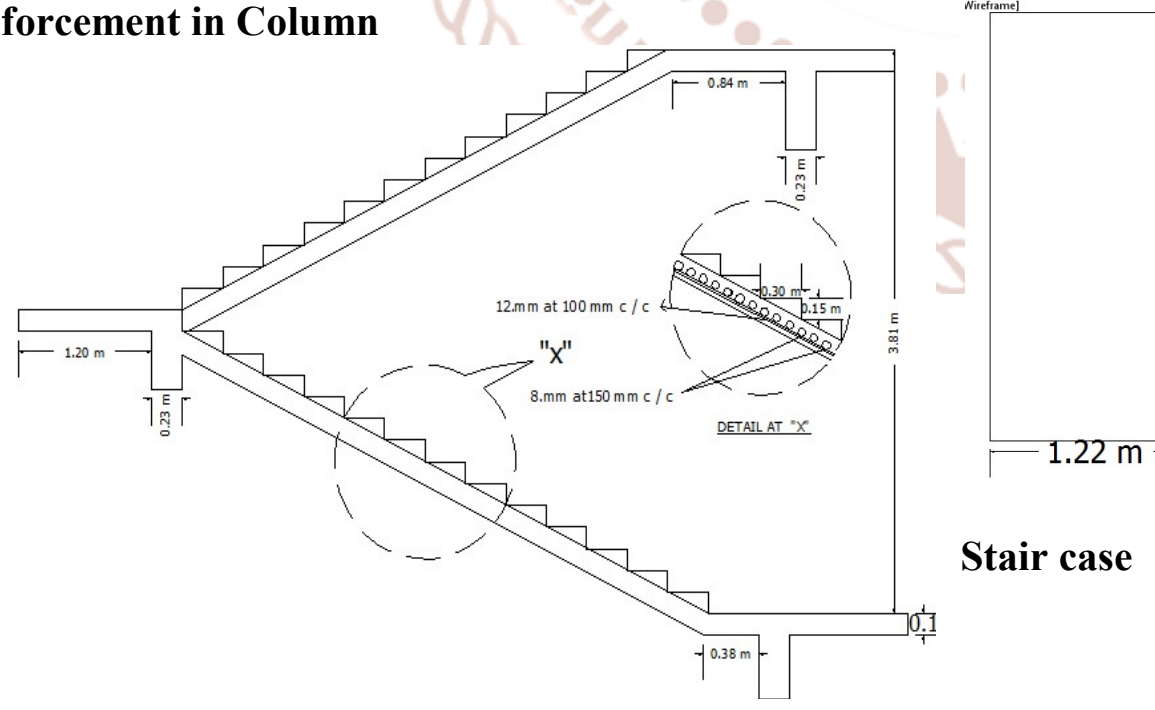




\section{CONCLUSION}

We can conclude that there is difference between the theoretical and practical work done. As the scope of understanding will be much more when practical work is done. As we get more knowledge in such a situation where we have great experience doing the practical work.

The structural components are designed as per code of practice IS 456-2000 in accordance to L.S.M. Knowing the loads we have designed the slabs depending upon the ratio of longer to shorter span of panel. In this project we have designed slabs as one way slabs depending upon the effective span. The calculations have been done for loads on beams and columns and designed frame analysis by moment distribution method.

\section{REFERENCES}

1. Vazirani V. N. and Ratwani M. M., Analysis of structures, Khanna publishers Delhi, 2010.

2. Hibbeler R. C., Structural Analysis sixth edition, Pearson Education, 2008

3. Dheerendra Babu M.R., Reinforced concrete structures, Falcon publishers Hyderabad, 2012.

4. Ashok K. Jain, Reinforced concrete, Nem Chand \& Bros., Roorkee 247 667, India, 2012.

5. Dr.B.C.Punmai, Ashok Kumar Jain, Arun Kumar Jain, Limit State Design of Reinforced Concrete, Laxmi Publications, 2007

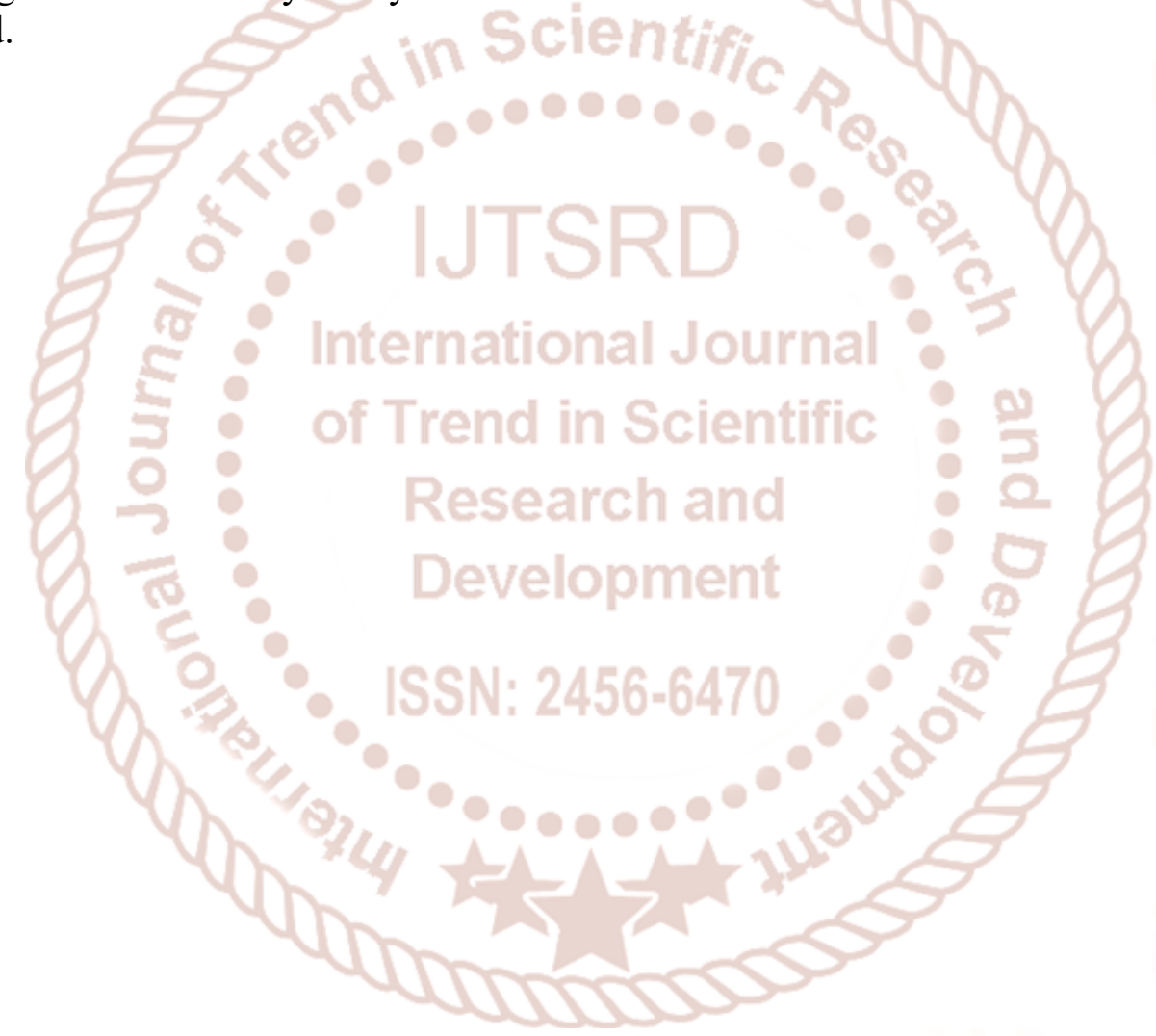

